Prepared in cooperation with the City of Rapid City

\title{
Stormwater Quality of Infrastructure Elements in Rapid City, South Dakota, 2016-18
}

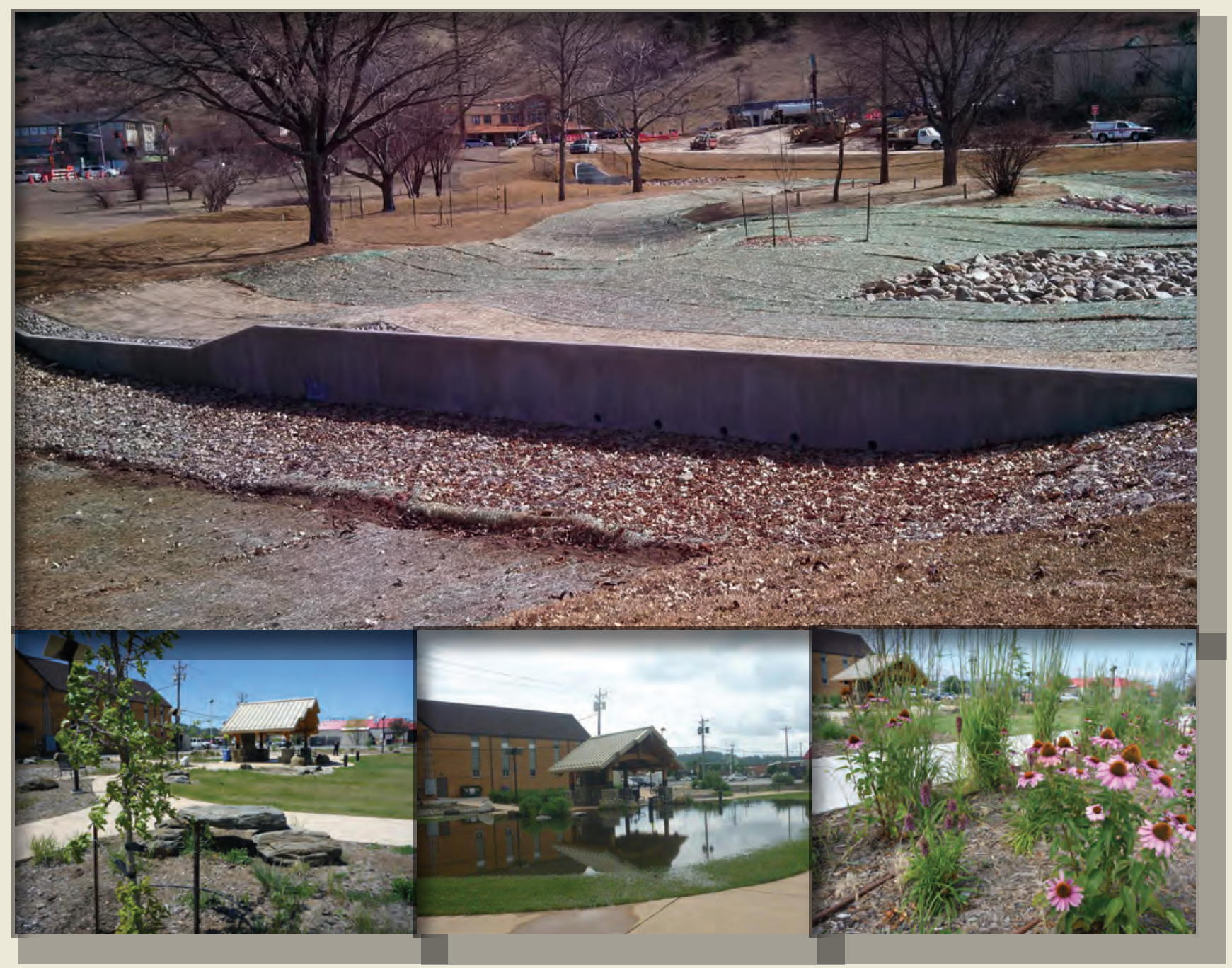

Scientific Investigations Report 2020-5004 
Cover: Upper photograph, Stormwater channel best-management practice near Jackson Boulevard in Rapid City, South Dakota. (Photograph by Galen Hoogestraat, U.S. Geological Survey). Lower photographs, Trinity Eco Prayer Park area near downtown Rapid City, South Dakota. (Photographs by Ken Steinken). 


\section{Stormwater Quality of Infrastructure Elements in Rapid City, South Dakota, 2016-18}

By Galen K. Hoogestraat

Prepared in cooperation with the City of Rapid City

Scientific Investigations Report 2020-5004 


\title{
U.S. Department of the Interior \\ DAVID BERNHARDT, Secretary
}

\author{
U.S. Geological Survey \\ James F. Reilly II, Director
}

U.S. Geological Survey, Reston, Virginia: 2020

For more information on the USGS - the Federal source for science about the Earth, its natural and living resources, natural hazards, and the environment—visit https://www.usgs.gov or call 1-888-ASK-USGS.

For an overview of USGS information products, including maps, imagery, and publications, visit https://store.usgs.gov/.

Any use of trade, firm, or product names is for descriptive purposes only and does not imply endorsement by the U.S. Government.

Although this information product, for the most part, is in the public domain, it also may contain copyrighted materials as noted in the text. Permission to reproduce copyrighted items must be secured from the copyright owner.

Suggested citation:

Hoogestraat, G.K., 2020, Stormwater quality of infrastructure elements in Rapid City, South Dakota, 2016-18: U.S.

Geological Survey Scientific Investigations Report 2020-5004, 24 p., https://doi.org/10.3133/sir20205004.

Associated data for this publication:

U.S. Geological Survey, 2019, USGS water data for the Nation: U.S. Geological Survey National Water Information System database, accessed September 5, 2019, at https://doi.org/10.5066/F7P55KJN.

ISSN 2328-0328 (online) 


\section{Acknowledgments}

The author would like to thank the staff from the City of Rapid City Public Works Department for providing technical guidance during this study. Appreciation is also given to the owners and staff from private facilities where sampling sites were located, including the Calvary Lutheran Church, Trinity Lutheran Church, and Eco Prayer Park (Ken Steinken). The author also would like to acknowledge the staff from the U.S. Geological Survey Dakota Water Science Center who supported the project by assisting with data collection, administration, and technical reviews. 



\section{Contents}

Acknowledgments ……...................................................................................................................

Abstract

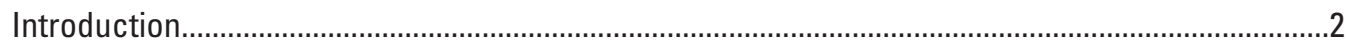

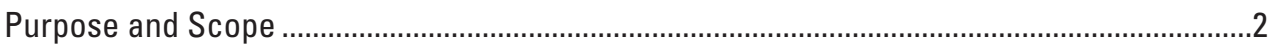

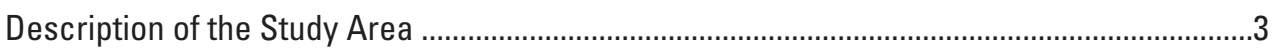

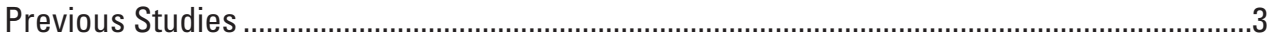

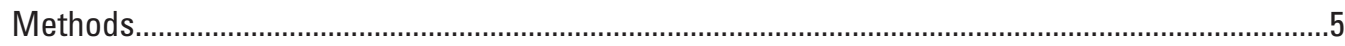

Selection and Description of Sampling Sites.........................................................................

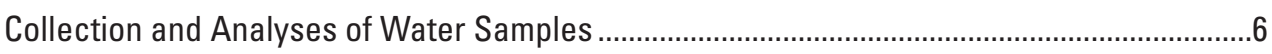

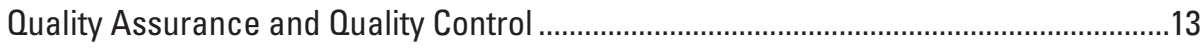

Stormwater Quality of Infrastructure Elements..........................................................................

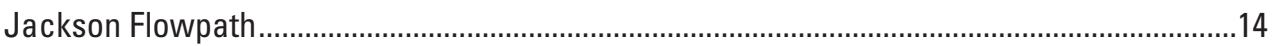

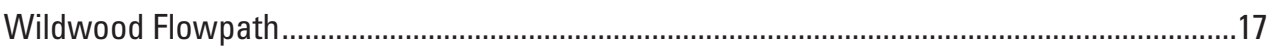

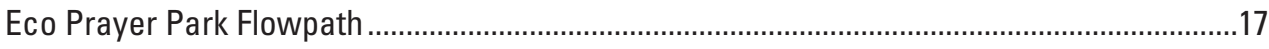

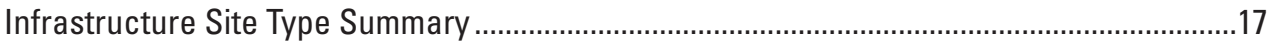

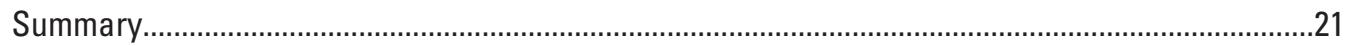

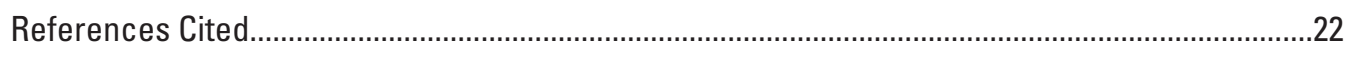

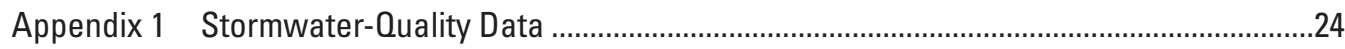

\section{Figures}

1. Map showing the study area, U.S. Geological Survey streamgages, and stormwater-quality flowpath site groups in Rapid City, South Dakota ..............................

2. Map showing the Jackson stormwater-quality flowpath sampling sites and drainage flowpath network in Rapid City, South Dakota...................................................7

3. Photographs showing the Jackson stormwater-quality flowpath sampling site types in Rapid City, South Dakota ...................................................................................

4. Map showing the Wildwood stormwater-quality flowpath sampling sites and drainage flowpath network, Rapid City, South Dakota......................................................

5. Photographs showing the Wildwood stormwater-quality flowpath sampling site types in Rapid City, South Dakota ................................................................................10

6. Map showing the Eco Prayer Park stormwater-quality flowpath sampling sites and drainage flowpath network in Rapid City, South Dakota...........................................11

7. Photographs showing the Eco Prayer Park stormwater-quality flowpath sampling site types in Rapid City, South Dakota.

8. Graphs showing example stormwater-quality data plot for Jackson flowpath on May 24, 2016

9. Graphs showing example stormwater-quality data plot for Wildwood flowpath on May 17, 2017

10. Graphs showing example stormwater-quality data plot for Eco Prayer Park flowpath on September 12, 2017 


\section{Tables}

1. U.S. Geological Survey site information for Rapid Creek sites near Rapid City, South Dakota

2. List of stormwater-quality sampling sites for the Jackson, Wildwood, and Eco Prayer Park flowpaths in Rapid City, South Dakota

3. Blank and replicate water-quality sample results for samples collected at various stormwater flowpath sites in Rapid City, South Dakota.

4. Summary statistics for water-quality results at stormwater sampling sites in Rapid City, South Dakota

5. Median Escherichia coli concentration, total suspended solids concentration, and specific conductance of site types sampled in 2016-18, Rapid City,

South Dakota

\section{Conversion Factors}

U.S. customary units to International System of Units

\begin{tabular}{lcl}
\hline & \multicolumn{1}{c}{ Multiply } & \multicolumn{1}{c}{ Bo obtain } \\
\hline inch (in.) & Length & \\
foot (ft) & 2.54 & centimeter $(\mathrm{cm})$ \\
mile (mi) & 0.3048 & meter $(\mathrm{m})$ \\
\hline \multicolumn{3}{c}{ Area } \\
\hline square mile $\left(\mathrm{mi}^{2}\right)$ & 1.609 & kilometer $(\mathrm{km})$ \\
\hline & 2.590 & square kilometer $\left(\mathrm{km}^{2}\right)$ \\
\hline cubic foot per second $(\mathrm{ft} 3 / \mathrm{s})$ & Flow rate & \\
\hline
\end{tabular}

Temperature in degrees Fahrenheit $\left({ }^{\circ} \mathrm{F}\right)$ may be converted to degrees Celsius $\left({ }^{\circ} \mathrm{C}\right)$ as follows: ${ }^{\circ} \mathrm{C}=\left({ }^{\circ} \mathrm{F}-32\right) / 1.8$.

\section{Datum}

Horizontal coordinate information is referenced to the North American Datum of 1983.

\section{Supplemental Information}

Specific conductance is given in microsiemens per centimeter at 25 degrees Celsius $(\mu \mathrm{S} / \mathrm{cm}$ at $25^{\circ} \mathrm{C}$ ).

Concentrations of chemical constituents in water are given in milligrams per liter (mg/L).

Water year (WY) is the 12-month period, October 1 through September 30, and is designated by the calendar year in which it ends. Thus, the water year ending September 30, 2016, is called the "2016" water year. 


\section{Abbreviations}

$\begin{array}{ll}\text { BMP } & \text { best management practice } \\ \text { CHN } & \text { open channel } \\ \text { CRB } & \text { street curb and gutter } \\ \text { DSP } & \text { downspout } \\ \text { E. coli } & \text { Escherichia coli } \\ \text { FIB } & \text { fecal indicator bacteria } \\ \text { PKL } & \text { parking lot } \\ \text { RPD } & \text { relative percent difference } \\ \text { TMDL } & \text { total maximum daily load } \\ \text { TSS } & \text { total suspended solids } \\ \text { USGS } & \text { U.S. Geological Survey } \\ \text { USS } & \text { underground storm sewer }\end{array}$





\title{
Stormwater Quality of Infrastructure Elements in Rapid City, South Dakota, 2016-18
}

\author{
By Galen K. Hoogestraat
}

\section{Abstract}

As runoff flows over the land or impervious surfaces (paved streets, parking lots, and building roofs), it accumulates debris, chemicals, sediment, and other contaminants that can adversely affect water quality if the runoff discharge remains untreated. Pathogens, commonly measured using fecal indicator bacteria such as Escherichia coli, enterococci, or fecal coliform, are the most-frequent cause of water-quality impairment in rivers and streams in the United States. Rapid Creek originates in the western Black Hills area and flows east through Rapid City, South Dakota, to its mouth at the Cheyenne River. The water quality of Rapid Creek is important because the reach that flows through Rapid City is a valuable spawning area for a self-sustaining trout fishery, is actively used for recreation, and is a seasonal municipal water supply for the City of Rapid City. These uses (fishery, recreation, and water supply) are considered beneficial uses by the South Dakota Department of Environment and Natural Resources. Numerical criteria have been established for total suspended solids and Escherichia coli concentrations, among other water-quality constituents, for these beneficial uses. The objectives of this study were to improve the method by which fecal indicator bacteria and total suspended solids are quantified in the urban drainages within Rapid City and to provide information that helps identify origins of fecal indicator bacteria and total suspended solids. This information can be used in hydrologic models to estimate fecal indicator bacteria and total suspended solid loading from certain infrastructure elements in urban environments.

Stormwater samples analyzed for Escherichia coli, total suspended solids, specific conductance, and $\mathrm{pH}$ were collected in three drainage basin flowpaths within Rapid City: Jackson, Wildwood, and the Eco Prayer Park. Data-collection activities for this study focused on upgradient urban flowpath elements during rainfall events. This approach builds upon previous stormwater assessments that characterized the water quality in urban basin outlets near the downstream end of the stormwater flowpaths. Within each flowpath group, 4-6 sites were selected to represent the various infrastructure elements of the runoff process. These elements included roof downspouts, parking lots, street curbs and gutters, open channels, underground storm sewers, and stormwater ponds or best-management practice facilities.
In general, the concentrations of Escherichia coli and total suspended solids increased in the downstream direction for all flowpath sites. The wash-off process after the first flush is evident for total suspended solids and specific conductance; however, Escherichia coli concentrations did not necessarily follow the same pattern. Escherichia coli concentrations in the latter part of the runoff period were similar to or greater than the initial concentrations of the first set of samples. Stormwater-quality data were summarized by infrastructure type (roof downspout, parking lot, street curb, and channel/ storm sewer) to provide information about approximate waterquality concentrations originating at the upper end of urban flowpaths. Escherichia coli and total suspended solid concentrations were lowest in samples collected from locations most isolated from human influence (roof downspouts); the median concentrations at these sites were 4 most probable number per 100 milliliters and 15 milligrams per liter, respectively. The delivery potential of fecal indicator bacteria and sediment from parking lots and street curbs was similar; median concentrations of Escherichia coli and total suspended solids were around 150-220 most probable number per 100 milliliters and 56-86 milligrams per liter, respectively. The downstream receiving channels and storm sewers where stormwater was aggregated typically contained the highest Escherichia coli concentrations (median was 1,800 most probable number per 100 milliliters), but the total suspended solid concentrations were similar to upstream elements in the flowpath (median was 69 milligrams per liter). The data collected from this study demonstrate that stormwater is contaminated with fecal indicator bacteria upon initial contact with impervious surfaces and highlight the importance of controlling the volume of stormwater discharges into receiving waterbodies via storage structures and pervious elements. Diluting stormwater with high concentrations of Escherichia coli with the receiving water's (Rapid Creek) lower concentration of Escherichia coli is likely the primary mechanism for meeting the beneficial-use criterion threshold of 235 most probable number per 100 milliliters. Although total suspended solid concentrations in the upper parts of the basin (parking lots and street curbs) also begin at concentrations ( 56 to 86 milligrams per liter) above the beneficial-use criterion for Rapid Creek (53 milligrams per liter), current stormwater-control practices (storage ponds, swales, and wetlands) may be able to reduce suspendedsediment concentrations to meet this threshold. 


\section{Introduction}

Stormwater runoff from urbanized lands can cause physical, biological, and chemical changes in the receiving waters, which can impair designated uses (U.S. Environmental Protection Agency, 2010). As runoff flows over the land or impervious surfaces (paved streets, parking lots, and building roofs), it accumulates debris, chemicals, sediment, or other contaminants that could adversely affect water quality if the runoff remains untreated. Pathogens are the mostfrequent cause of water-quality impairment in rivers and streams in the United States; more than 180,000 river miles are listed as impaired by pathogens on State 303(d) lists (U.S. Environmental Protection Agency, 2019; American Society of Civil Engineers, 2014). Pathogen impairments usually are identified based on elevated counts of fecal indicator bacteria (FIB), such as Escherichia coli (E. coli), enterococci, or fecal coliform. Sediment is the secondmost-frequent cause of water-quality impairment in rivers and streams in the United States; more than 130,000 river miles are listed as impaired by sediment on State 303(d) lists (U.S. Environmental Protection Agency, 2019).

Rapid Creek is a valuable natural resource, and protecting its water quality is important because the reach that flows through Rapid City, South Dakota, is a critical spawning area for a self-sustaining trout fishery, is actively used for recreation, and is a seasonal municipal water supply for the City of Rapid City. Per the Clean Water Act, the South Dakota Department of Environment and Natural Resources (DENR) lists beneficial uses of major streams and rivers in the State. For example, Rapid Creek through Rapid City has beneficial uses of domestic water supply, coldwater permanent fish life propagation, immersion recreation, and limited-contact recreation (South Dakota Department of Environment and Natural Resources, 2010). For total suspended solids (TSS), the most restrictive of the water-quality requirements is related to the beneficial use of cold-water permanent fish life propagation. The water-quality standard/requirement for TSS is a geometric-mean concentration not to exceed 30 milligrams per liter $(\mathrm{mg} / \mathrm{L})$ during a 30 -day period, and a single sample should not exceed $53 \mathrm{mg} / \mathrm{L}$. Immersion recreation carries a designation based on FIB concentrations: E. coli concentrations should not exceed 126 most probable number per 100 milliliters $(\mathrm{mpn} / 100 \mathrm{~mL})$ during a 30-day period or $235 \mathrm{mpn} / 100 \mathrm{~mL}$ for a single sample (South Dakota Department of Environment and Natural Resources, 2010).

During 2014, water quality in Rapid Creek for reaches upstream from Rapid City met designated beneficial-use water-quality standards; however, Rapid Creek from Canyon Lake to the Cheyenne River was impaired because of excessive fecal coliform, E. coli, or both bacteria levels (South Dakota Department of Environment and Natural Resources, 2014). A recent compilation of water-quality data for Rapid City drainages documented event-mean concentrations for E. coli of 7,200 to $21,000 \mathrm{mpn} / 100 \mathrm{~mL}$ in developed basins (Hoogestraat, 2015), demonstrating the presence of high FIB concentrations entering Rapid Creek during runoff. A total maximum daily load (TMDL) criterion for FIB for reaches within and downstream from Rapid City was approved by the South Dakota DENR in 2010. A TMDL is a calculation of the maximum amount of a pollutant that a waterbody can receive and still meet water-quality standards (South Dakota Department of Environment and Natural Resources, 2019).

Approval of a TMDL for a waterbody commonly is followed by an implementation project with goals to reduce pollution sources within the drainage basin. Major purposes of the TMDL assessment are to identify potential causes or sources of the water-quality impairment and to suggest bestmanagement practices (BMPs) for reducing those impairments (South Dakota Department of Environment and Natural Resources, 2019). Methods of identifying FIB impairments in surface water are usually limited to a general assessment of sources (typically grouped as livestock, wildlife, or human). For the Rapid Creek bacteria TMDL, FIB load estimates were derived from the Bacteria Indicator Tool (U.S. Environmental Protection Agency, 2000), which models loads primarily based on land-use classifications. This derivation is common for bacteria TMDLs because FIB sample data about specific sources typically are not available. The lack of data to connect FIB concentrations in receiving waterbodies to its actual sources represents an area of needed research in the TMDL process. Implementation projects may target a source within the watershed that does not contribute to the FIB load, and those sources that do contribute FIB load are overlooked. An improvement on this process would include collecting FIB data from various flowpaths, which would allow for isolating and targeting specific contributing areas where FIB is known to originate. The U.S. Geological Survey (USGS), in cooperation with the City of Rapid City, began a stormwaterquality study in 2016 to improve the method by which FIB and TSS are quantified in the urban drainages within Rapid City and to provide information that helps identify origins of FIB and TSS.

\section{Purpose and Scope}

The purposes of this report are to describe the methods and data collected from urban flowpath sites in Rapid City during 2016-18 and to provide statistical summaries of the water-quality data for the various infrastructure site types that were sampled for the stormwater-quality study. This information could be used in hydrologic models to estimate FIB and TSS loading from certain infrastructure elements in urban environments. This study only involved data collection within the city of Rapid City; however, the results are transferable to urban drainages in cities with similar infrastructure and climate. 


\section{Description of the Study Area}

Stormwater datasets were collected in 3 urban flowpaths within Rapid City: Jackson (6 sampling sites), Wildwood (6 sampling sites), and Eco Prayer Park (4 sampling sites; fig. 1). Rapid City has a population of about 75,000 (U.S. Census Bureau, 2019) and is in the eastern foothills of the Black Hills. Within the city limits, the areas developed with the most impervious infrastructure are along the Highway 16/I-190 corridor and to the east (fig. 1). The west side of Rapid City generally has less intense development, more open space, and natural grass-lined drainage channels. The Rapid City region is susceptible to short-duration, intense, convective thunderstorms during the spring and summer months (Driscoll and others, 2010). The mean annual (1981-2010) precipitation for Rapid City is 19.8 inches, of which 12.0 inches fall during April-July (National Oceanic and Atmospheric Administration, 2014).

Rapid Creek originates in the western Black Hills area and flows east through Rapid City to its mouth at the Cheyenne River (fig. 1). The mean annual streamflow for Rapid Creek above Canyon Lake (USGS streamgage 06412500; fig. 1; table 1) was 56 cubic feet per second ( $\mathrm{ft} 3 / \mathrm{s})$ during water years 1981-2017 with a drainage area of 374 square miles $\left(\mathrm{mi}^{2}\right)$. All streamflow data are from the USGS National Water Information System (U.S. Geological Survey, 2019). The mean annual streamflow for Rapid Creek at Rapid City (USGS streamgage 06414000 ) was $77 \mathrm{ft}^{3} / \mathrm{s}$ with a drainage area of $413 \mathrm{mi}^{2}$. The mean annual streamflow for Rapid Creek below the sewage treatment plant near Rapid City (USGS streamgage 06418900 , not shown on fig. 1, located 2 miles east) was $90 \mathrm{ft} 3 / \mathrm{s}$ with a drainage area of $456 \mathrm{mi}^{2}$.

Mean annual streamflow increases $21 \mathrm{ft} 3 / \mathrm{s}$ in the $39 \mathrm{mi}^{2}$ between the streamgage on the upstream west boundary (streamgage 06412500) and in the middle (streamgage 06414000) of Rapid City. This increase includes mean annual springflow of about $14 \mathrm{ft} 3 / \mathrm{s}$ from two springs on the west side of Rapid City (streamgages 06412810 and 06413650; fig. 1; table 1). The remaining $7 \mathrm{ft} 3 / \mathrm{s}$ increase in mean annual streamflow can be attributed to the predominantly developed, urban $39-\mathrm{mi}^{2}$ drainage area, or an increase of $0.18 \mathrm{ft} 3 / \mathrm{s}$ per square mile of drainage area on the west side of Rapid City. Mean annual streamflow increases $13 \mathrm{ft} 3 / \mathrm{s}$ in the $43 \mathrm{mi}^{2}$ between the streamgage in the middle (streamgage 06414000) and on the downstream east boundary (streamgage 06418900 ) of Rapid
City, or $0.29 \mathrm{ft} 3 / \mathrm{s}$ per square mile of drainage area on the east side of Rapid City. The mean annual streamflow of Rapid Creek increases a total of $34 \mathrm{ft} 3 / \mathrm{s}$ ( 60 percent) between the upstream and downstream boundaries of Rapid City (which includes the $14 \mathrm{ft} 3 / \mathrm{s}$ from springflow), or an increase of $20 \mathrm{ft} 3 / \mathrm{s}$ (37 percent) from the intervening urban drainage area without including springflow.

\section{Previous Studies}

In the past 40 years, several studies have examined stormwater runoff in the Rapid City area, mostly focusing on the quantity and quality of runoff as it enters Rapid Creek. Hoogestraat (2015) provides the most recent compilation of stormwater information in the Rapid City area, wherein stormwater quality was assessed in three urban drainages during 2008-14. In that study, event-mean concentrations of TSS and FIB typically exceeded relevant beneficial-use criteria for Rapid Creek by 1-2 orders of magnitude. Three wetland channels at the outlet of an urban drainage basin were assessed for contaminant removal capability. The assessment indicated that these treatment controls were capable of reducing TSS concentrations by 40 percent; however, bacteria removal rates were lower, and in some cases, concentrations increased (Hoogestraat, 2015). Pirner and Harms (1978) studied urban runoff as a potential source of pollution in Rapid Creek. The Nationwide Urban Runoff Program chose Rapid City as one of its study locations during the early 1980s and analyzed numerous water-quality constituents (U.S. Environmental Protection Agency, 1983). Prann (2013) evaluated the effect of impervious surfaces in Rapid City on water quality using calibrated hydrologic models.

These local studies indicated that TSS and bacteria concentrations in stormwater runoff have the potential to adversely affect water quality in the Rapid Creek drainage basin; however, research regarding sources of the bacteria or loading estimates from the headwaters (urban infrastructure) is sparse. A study in southern California (Tiefenthaler and others, 2011) quantified the relative levels and flux patterns of E. coli, enterococci, and total coliforms from representative land-use types (such as high-density residential, industrial, or commercial). Bacteria and sediment loads from urban infrastructure have been estimated most frequently using model simulations (Riebschleager and others, 2012; Granato, 2013). 


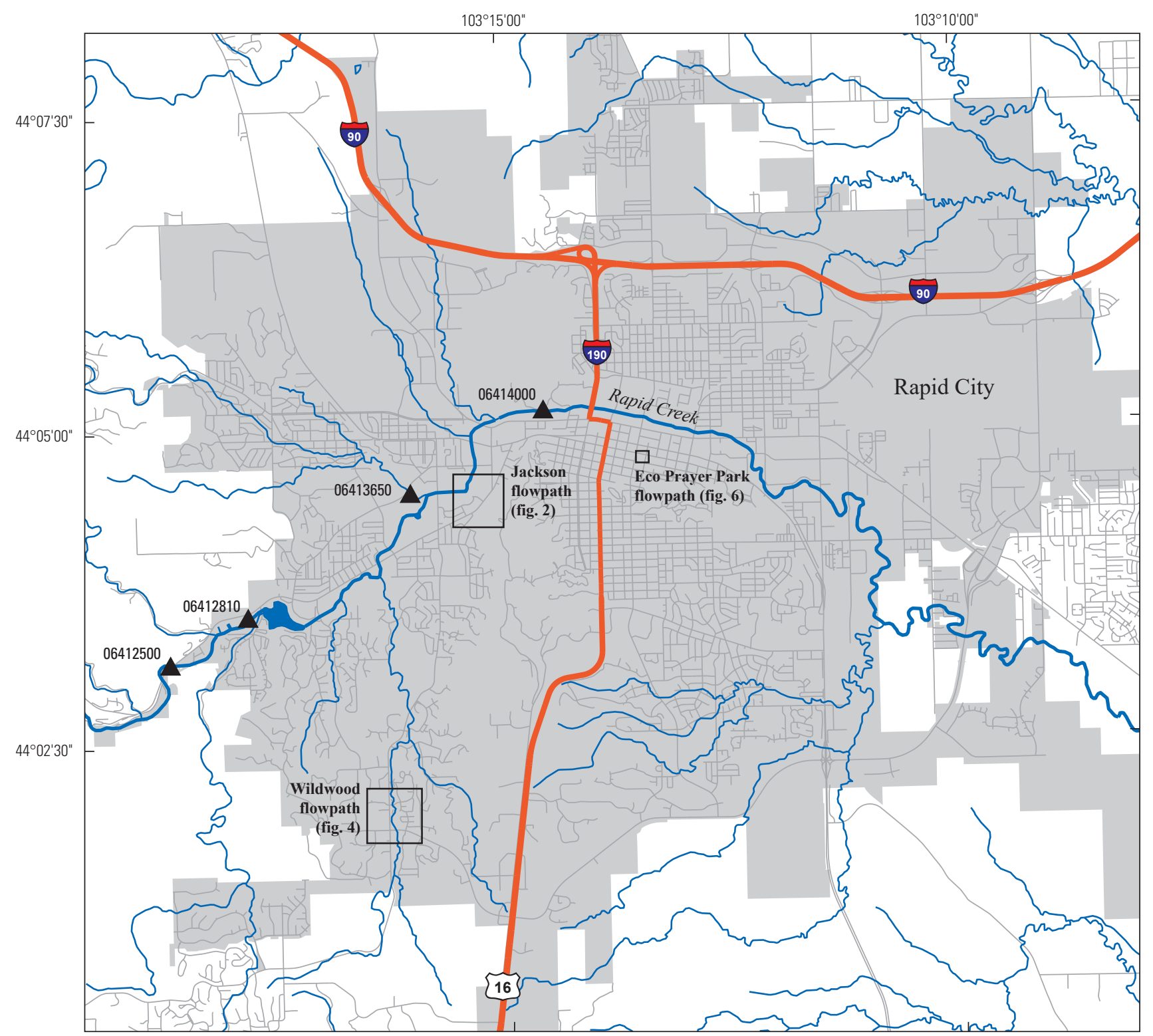

Base from U.S. Geological Survey digital data Universal Transverse Mercator Projection, Zone 13 North

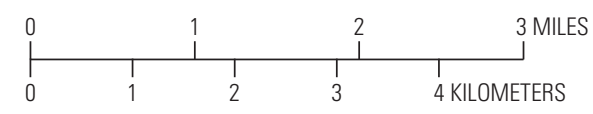

\section{EXPLANATION}

\section{Drainage flowpath}

06414000 U.S. Geological Survey streamgage and identifier

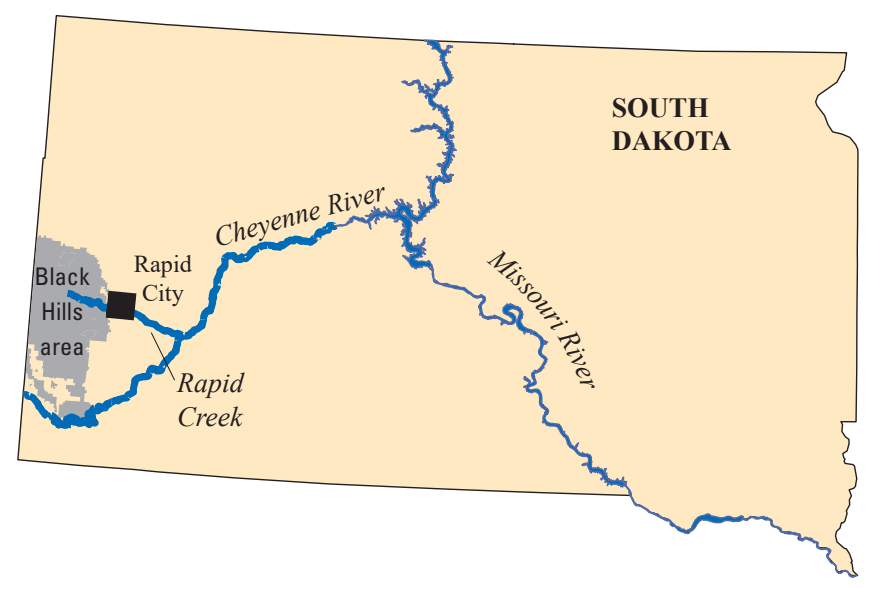

Figure 1. Study area, U.S. Geological Survey streamgages, and stormwater-quality flowpath site groups in Rapid City, South Dakota. 
Table 1. U.S. Geological Survey site information for Rapid Creek sites near Rapid City, South Dakota.

[Data are from the National Water Information System database (U.S. Geological Survey, 2019). $\mathrm{mi}^{2}$, square mile; ft 3 s, cubic foot per second; --, not applicable]

\begin{tabular}{llccc}
\hline $\begin{array}{c}\text { U.S. Geological } \\
\text { Survey site number }\end{array}$ & \multicolumn{1}{c}{ U.S. Geological Survey site name } & $\begin{array}{c}\text { Drainage } \\
\text { area (mi2) }\end{array}$ & $\begin{array}{c}\text { Mean an- } \\
\text { nual flow } \\
\text { (ft3/s) }\end{array}$ & $\begin{array}{c}\text { Data period } \\
\text { Did }\end{array}$ \\
\hline 06412500 & Rapid Creek above Canyon Lake near Rapid City, South Dakota & 374 & 56 & $1981-2017$ \\
\hline 06412810 & Cleghorn Springs at Rapid City, South Dakota & -- & 12 & $1993-2017$ \\
\hline 06413650 & Lime Creek at Mouth at Rapid City, South Dakota & 9.8 & 2 & $1988-2002$ \\
\hline 06414000 & Rapid Creek at Rapid City, South Dakota & 413 & 77 & $1981-2017$ \\
\hline 06418900 & $\begin{array}{l}\text { Rapid Creek below sewage treatment plant near Rapid City, South } \\
\text { Dakota }\end{array}$ & 456 & 90 & $1981-2017$ \\
\hline
\end{tabular}

\section{Methods}

Data-collection activities for this study focused on the upgradient urban flowpath elements during rainfall, including roof downspouts, parking lots, street curbs, and drainage channels. The sampling plan started at the source (beginning) of the urban flowpath (roof) and moved downgradient along the urban flowpath. This approach builds upon a previous stormwater assessment (Hoogestraat, 2015) that characterized the water quality in urban basin outlets near the downstream end of the stormwater flowpaths. Three flowpath site groups, which are in separate areas within Rapid City (fig. 1), were sampled for water quality in 2016-18. Within each flowpath group, 4-6 sites were selected to represent the various elements of the runoff process. These elements include roof downspouts (DSP), parking lots (PKL), street curbs and gutters (CRB), open channels (CHN), underground storm sewers (USS), and stormwater ponds or BMP facilities.

\section{Selection and Description of Sampling Sites}

The flowpath sampling sites were selected based on several factors: availability of previous water-quality data within the same drainage, previous undocumented observations of flow, sampling logistics (quick response for personnel during runoff events), and presence of multiple infrastructure element types within a short flowpath distance. These selected sites (table 2) were used to examine the potential bacteria and sediment loads of various infrastructure elements. The Jackson flowpath sites were selected based on ease of sampling logistics (quickest access for staff during runoff events) and because they included a mix of multiple infrastructure types in a short flowpath distance. The Wildwood flowpath sites were selected based on sampling logistics and on the availability of multiple infrastructure drainage sources (street curb and parking lots) nearby and because stormwater-quality data were previously collected downstream within the same drainage (Hoogestraat, 2015). The Eco Prayer Park sites were selected because they were in an area where best-management practices (stormwater-treatment area) were in place and where well-defined inflow and outflow points existed.

Each of the three flowpaths represents a unique set of land-use characteristics that affect stormwater quality. The Jackson flowpath (figs. 2-3) originates at a commercial office complex (fig. $3 A$ ) and includes a curb (fig. $3 B$ ), an underground storm sewer (fig. $3 C$ ), and an open concrete-lined channel flow before flowing into an infiltration trench/retention area (fig. 3D). The Jackson flowpath sampling sites represented all infrastructure types targeted in this study, including a roof downspout, parking lot, underground storm sewer, open drainage channel, and BMP channel outlet. Samples were generally collected at the downspout, parking lot, and street curb sites before sample collection at the channel and storm sewer sites farther down the flowpath. The channel and storm sewer sites (table 2) in the Jackson flowpath (WTP-USS, WTP-CHN, and WTP-BMP) included stormwater drainage from a highly developed commercial corridor area (northwest corner of fig. 2) not represented by the upstream flowpath sites (USG-DSP, USG-PKL, and USG-CRB).

The Wildwood flowpath contains a mix of low-density residential and commercial uses in the drainage area. The upper end of the Wildwood flowpath (figs. 4-5) contains primarily low-density residential lots with septic systems. When FIB are detected in surface water that originates from these areas, a common hypothesis has been that septic systems are a likely source; however, past monitoring has indicated that higher bacteria concentrations are often measured in Rapid City urban basins that do not have septic systems (Hoogestraat, 2015). The Wildwood flowpath includes commercial parking lot outfalls, curb discharges, and grass-lined channels in the same general area. The Wildwood flowpath sampling sites (table 2; fig. 4) included 1 roof downspout (CLC-DSP; fig. 5C), 2 parking lots (CLC-PKL and ATHPKL; figs. $5 A$ and $5 D$ ), 2 street curbs (WDW-CRB and SDC-CRB; figs. $5 B$ and $5 E$ ), and 1 open grass-lined drainage channel (SDC-CHN; fig. 5E).

The Eco Prayer Park flowpath (figs. 6-7) represents the most uniform land use because the basin elements are completely impervious. FIB and sediment from this flowpath can 
Table 2. List of stormwater-quality sampling sites for the Jackson, Wildwood, and Eco Prayer Park flowpaths in Rapid City, South Dakota.

Site information is from the National Water Information System database (U.S. Geological Survey, 2019).

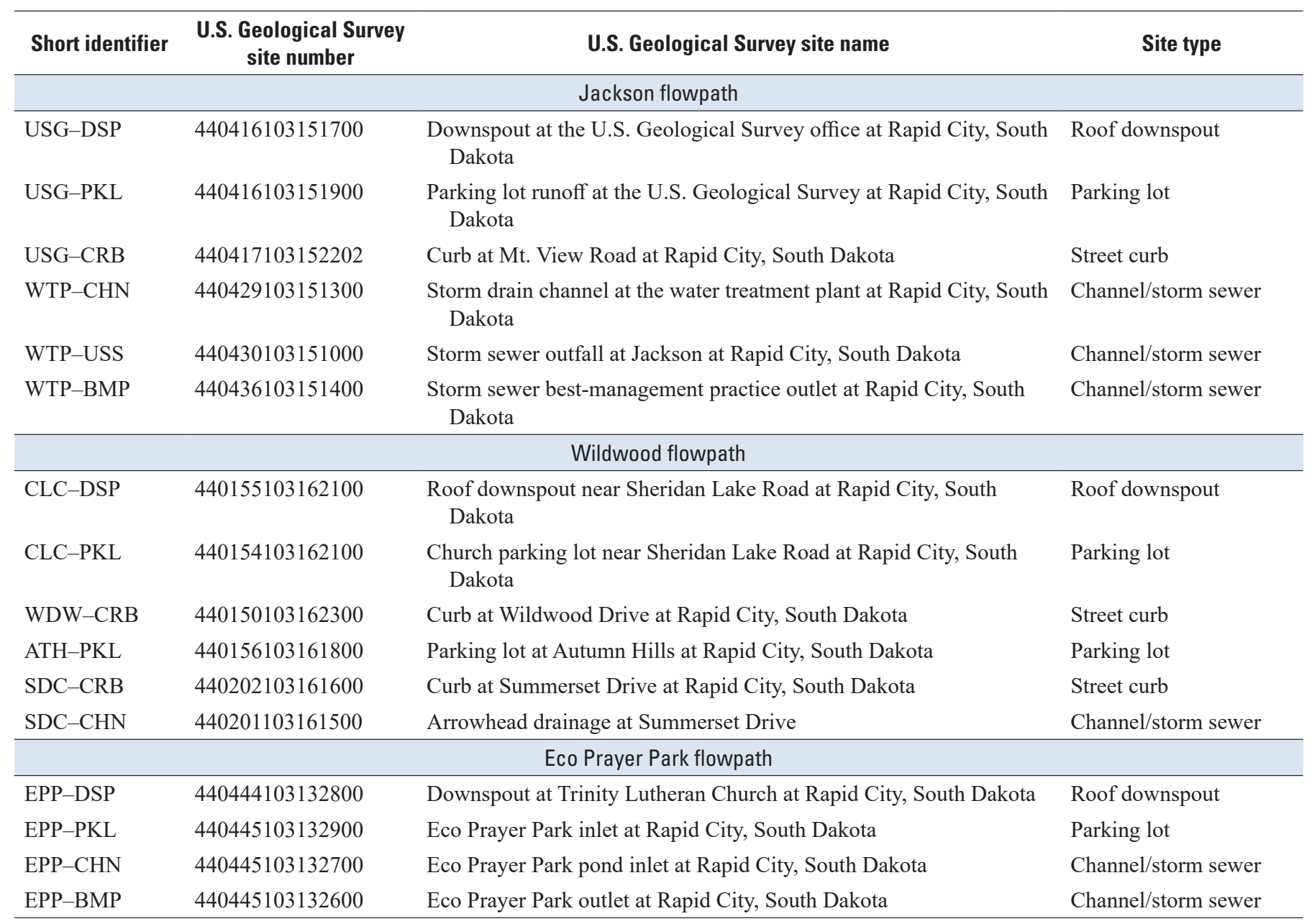

be attributed entirely to commercial uses and street traffic. The Eco Prayer Park flowpath sites (table 2) included 1 roof downspout (EPP-DSP; fig. 7A), 1 parking lot (EPP-PKL; fig. 7B), 1 rock-lined channel (EPP-CHN; fig. 7C), and 1 outlet from a small retention pond BMP (EPP-BMP; fig. 7D). A stage plate was installed in the retention pond to record changes in the water level during runoff at the EPP-BMP site (fig. 7D). During high inflows to the Eco Prayer Park, the flow splits between the rock channel and an overflow path into a grassed lawn area to the north side (fig. 6). This grassed lawn contains underdrains that flow back into the retention pond.

\section{Collection and Analyses of Water Samples}

Water-quality samples were collected at each flowpath site during storm events during May-September in 2016-18. A storm event was defined as having at least 0.10 inch of precipitation that was separated by at least 72 hours of preceding dry weather conditions. Collection generally began at the upstream sites and continued downstream in consecutive order. Multiple samples were collected at each flowpath site during runoff events to capture the variability in water-quality concentrations as the runoff hydrograph rises ("first flush" process) and falls after the peak runoff (when material from impervious surfaces have "washed off"). The number of samples collected at each flowpath site during a sampling event varied depending on the duration of precipitation and the resulting runoff. Estimates of depth of flow using a ruler or wading rod were made at each site during sample collection to assess whether the runoff was increasing or decreasing, but depth or flow information are not presented in this report.

Water-quality samples were collected by USGS personnel and analyzed for E. coli and TSS by Mid Continent Testing Laboratories (Rapid City, S. Dak.) according to standard procedures (American Public Health Association, 2015). Standard procedures for water-quality sample collection followed the USGS National Field Manual (U.S. Geological Survey, 2006). Bottles used in sampling procedures were routinely cleaned 


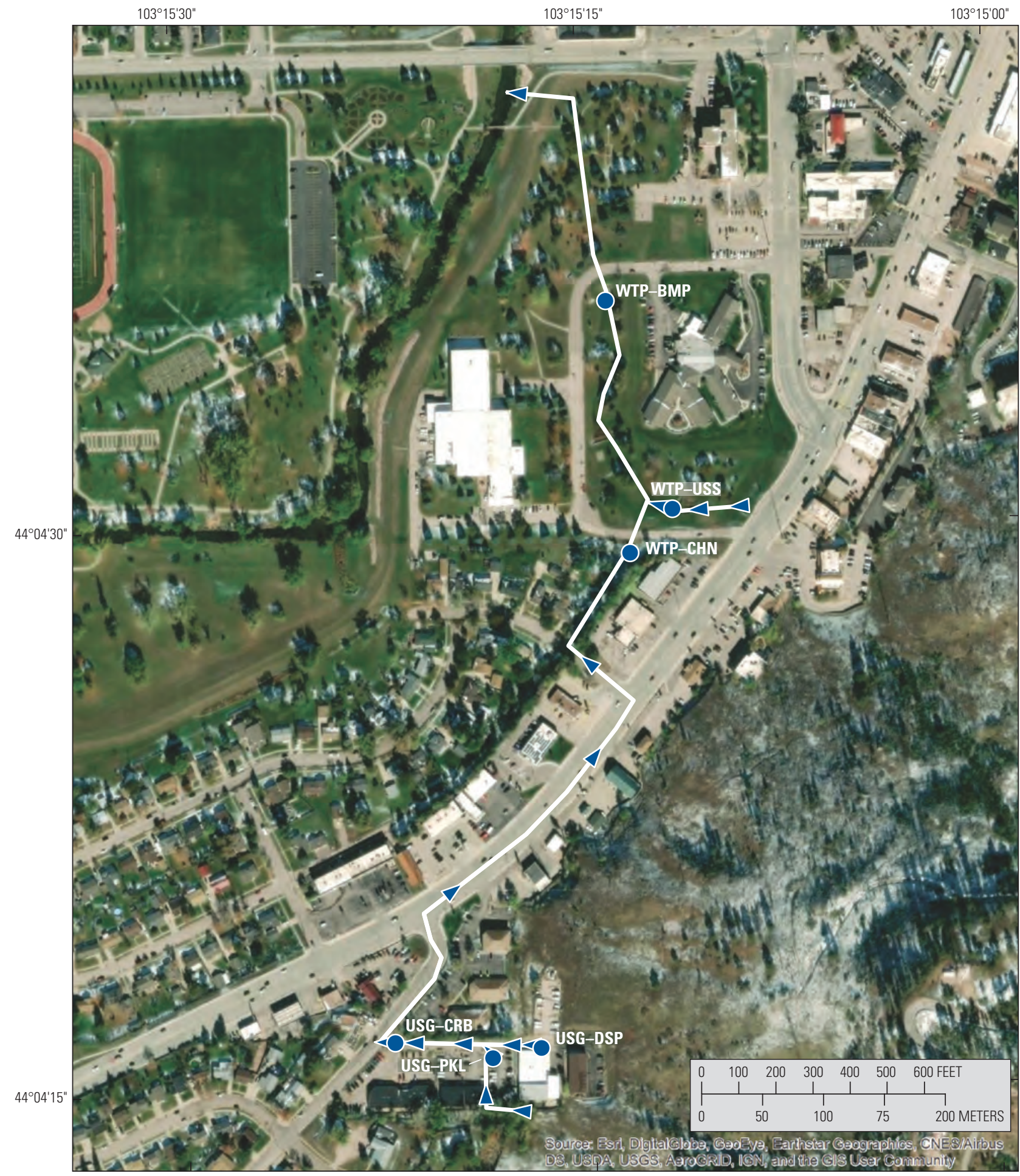

Base from U.S. Geological Survey digital data

Map image is the intellectual property of Esri and is used herein under license.

Copyright ( 12014 Esri and its licensors. All rights reserved.

Universal Transverse Mercator projection

Zone 13 North

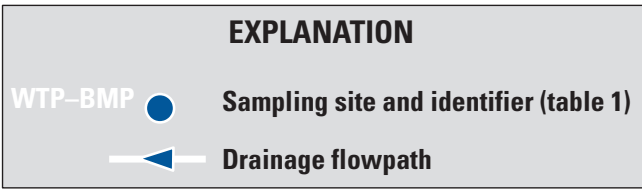

Figure 2. Jackson stormwater-quality flowpath sampling sites and drainage flowpath network in Rapid City, South Dakota. 

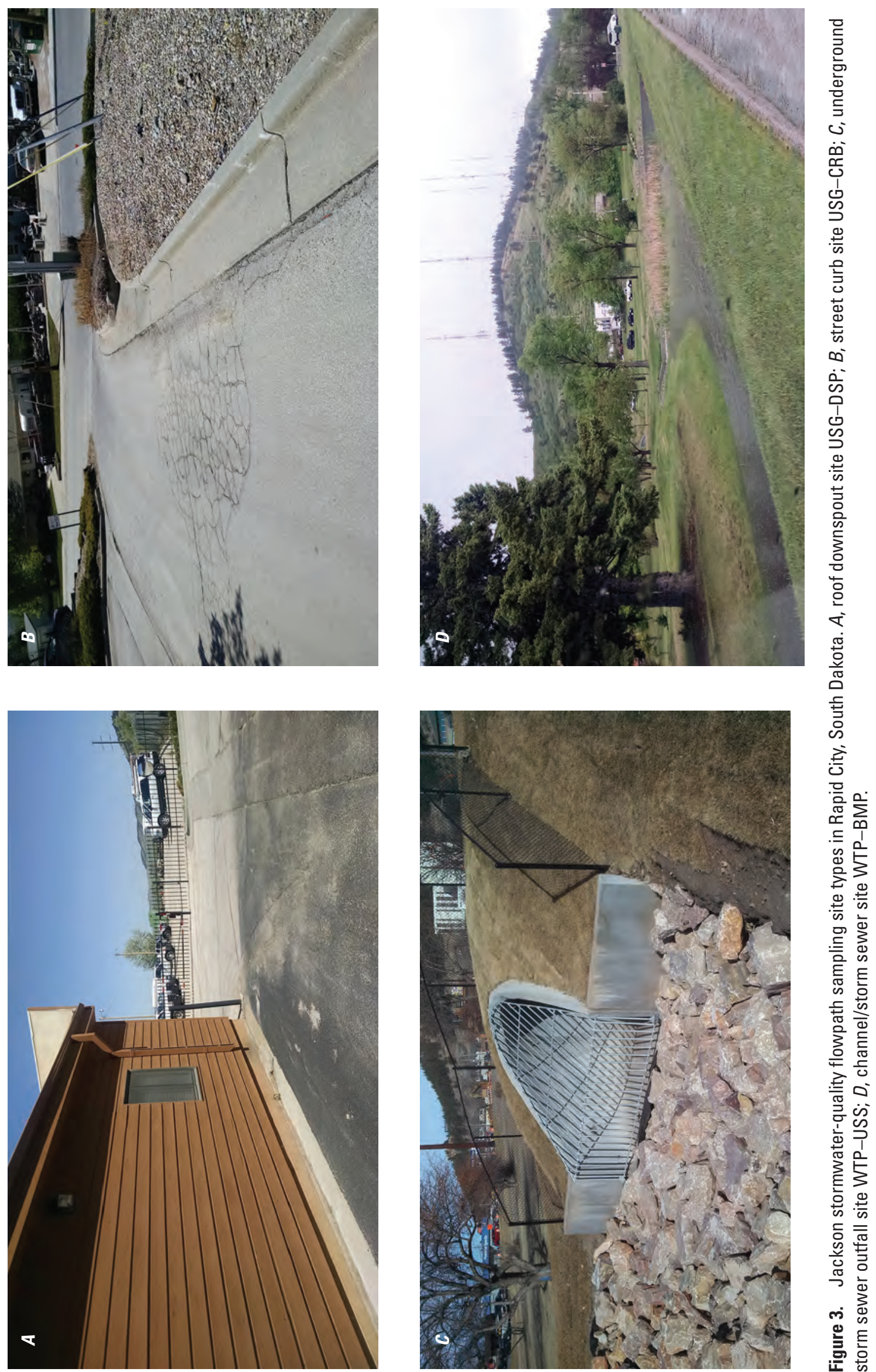

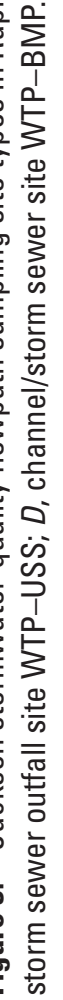




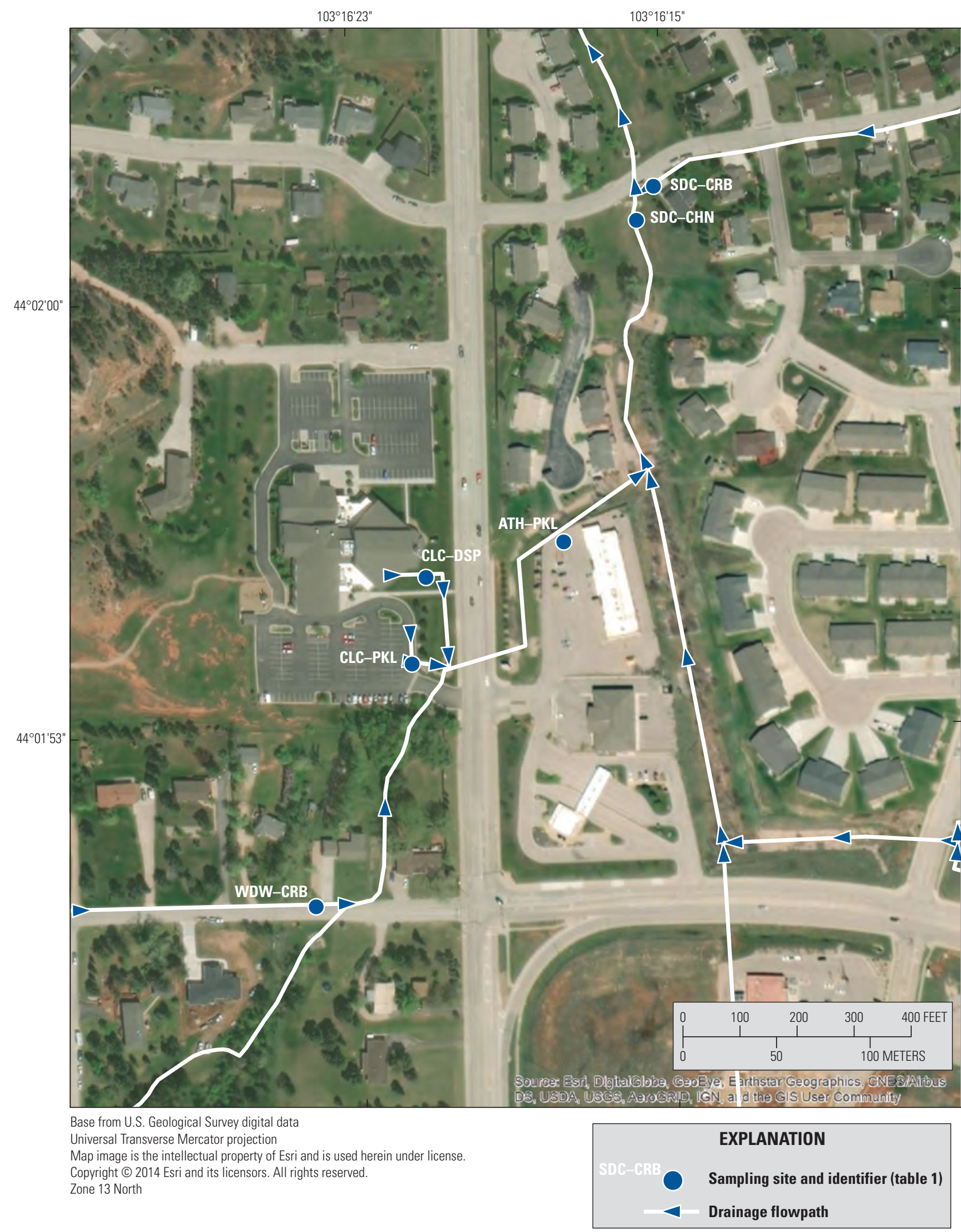

Figure 4. Wildwood stormwater-quality flowpath sampling sites and drainage flowpath network, Rapid City, South Dakota. 


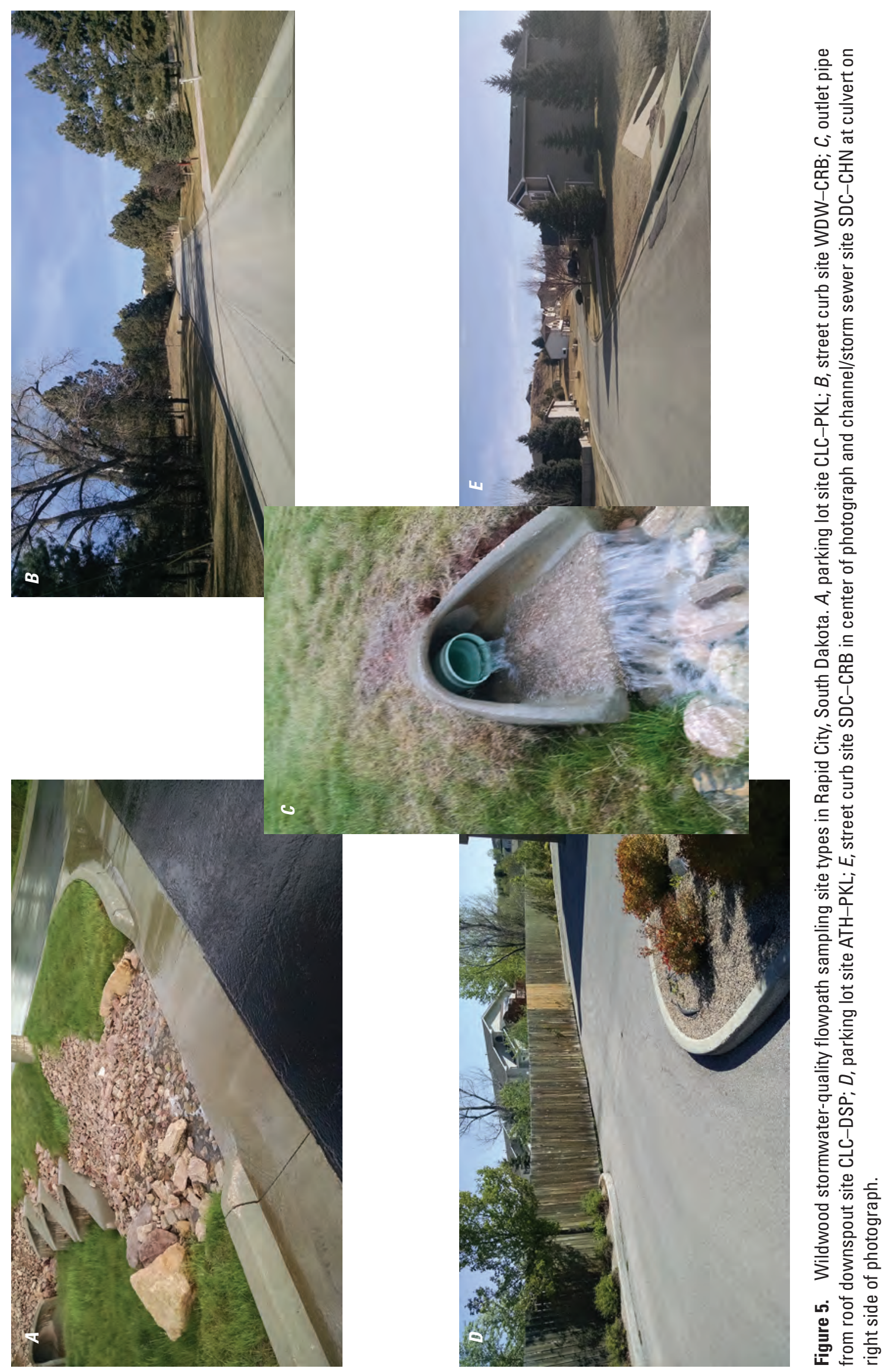




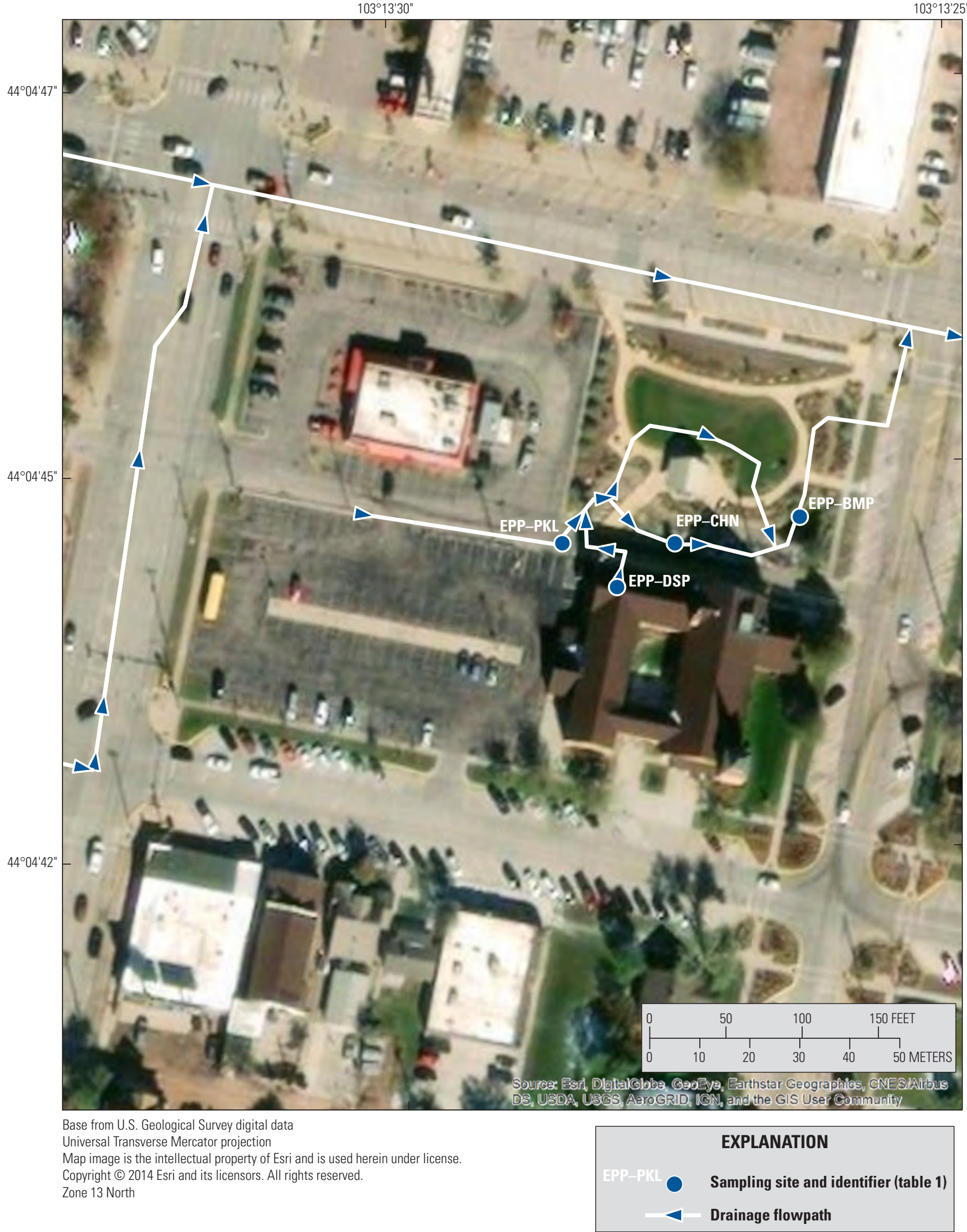

Figure 6. Eco Prayer Park stormwater-quality flowpath sampling sites and drainage flowpath network in Rapid City, South Dakota. 


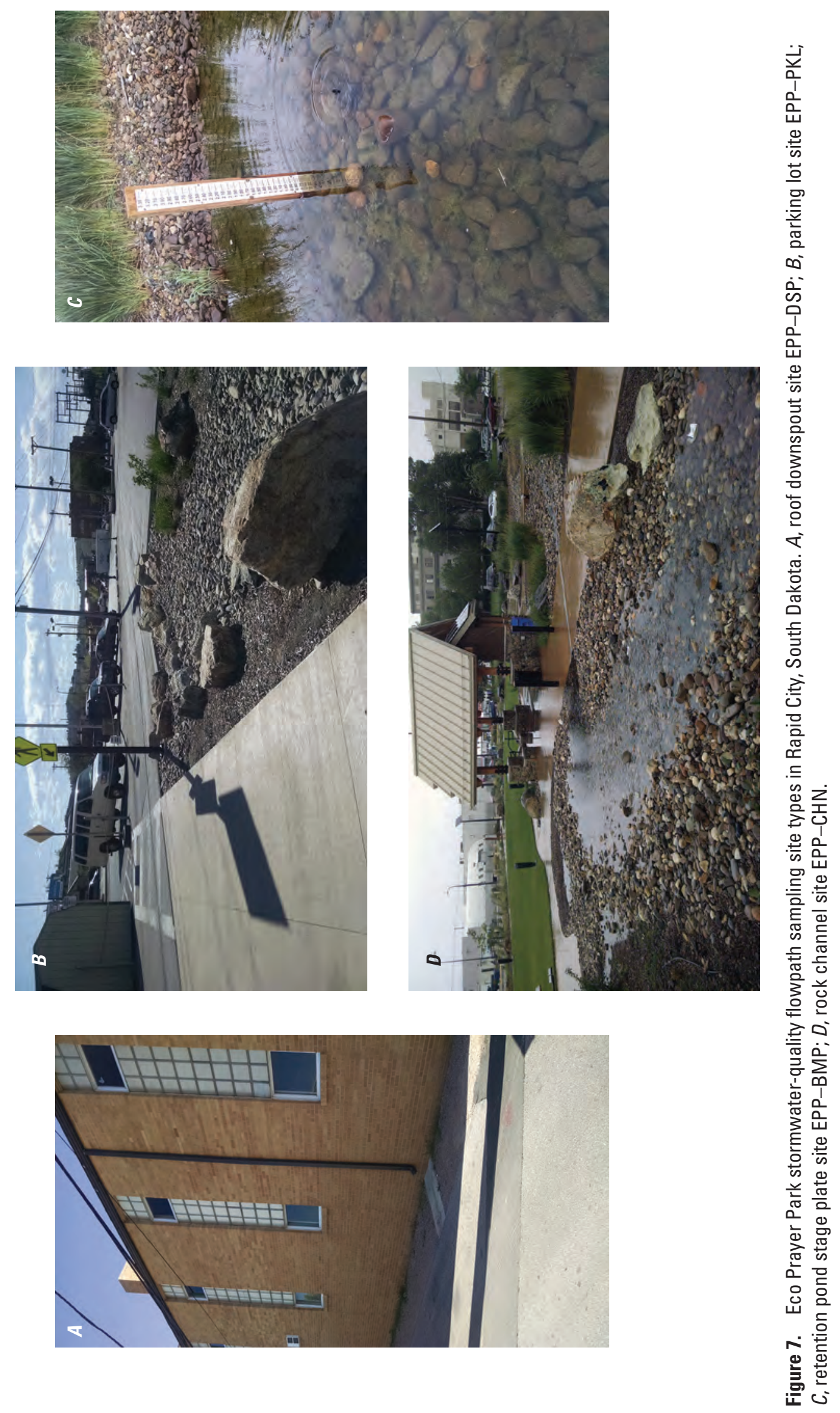


as described in the USGS National Field Manual (Wilde, 2004) or replaced after sampling. Samples were collected in sterile 1-liter plastic bottles using grab-sampling techniques (U.S. Geological Survey, 2006). Flow at most sites was confined to relatively narrow channels (such as a downspout or curb) or through a culvert pipe, so width- and depthintegrating sampling techniques were not feasible or warranted. Sample bottles were brought to the USGS Rapid City laboratory where specific conductance and $\mathrm{pH}$ values were measured, and water samples were transferred into containers supplied by Mid Continent Testing Laboratories.

Specific conductance is a measure of the ability of water to conduct an electrical current and is a surrogate measure of dissolved solids (Hem, 1985). For stormwater samples, specific conductance usually correlates with total dissolved solids (Granato and Smith, 1999) and is used to help assess the wash-off process. The wash-off process refers to decreases in suspended and dissolved solids concentrations with time during a storm event. Pure liquid rainwater has a very low specific conductance (less than 100 microsiemens per centimeter at 25 degrees Celsius; Hem, 1985), and thus, stormwater samples collected during the receding limb of a runoff hydrograph typically have specific conductance values much less than the rising limb of the hydrograph (also referred to as the "first flush"). Although $\mathrm{pH}$ data were also collected with samples, no analyses of the results were completed for this report; however, the results are available with other water-quality constituents in appendix 1 (U.S. Geological Survey, 2019).

\section{Quality Assurance and Quality Control}

Quality-assurance and quality-control procedures were used to identify possible random or systemic errors in the field sampling and laboratory analyses. For quality control, equipment blank and sequential replicate samples were collected to determine precision and identify potential sample contamination. During the 3-year study, 147 environmental water-quality samples were collected for laboratory analyses, and 9 qualitycontrol samples were collected. Five equipment blanks were collected to assess the sample equipment cleaning procedures and laboratory methods, and four sequential replicate samples were collected to measure variability associated with sample collection, processing, and analysis (table 3 ).

Precision of analytical results for water-quality samples may be affected by numerous sources of potential variability in field and laboratory processes, including sample collection, sample processing and handling, and laboratory preparation and analysis. Analyses of field replicate samples, therefore, can indicate the reproducibility of environmental data and provide information on the variability associated with sample collection and analysis. The precision of environmental/replicate sample pairs can be assessed using the absolute difference in concentrations and the relative percent difference (RPD), calculated as the difference in concentration divided by the mean concentration multiplied by 100 for the environmental/ replicate pair. For E. coli concentrations in environmental/ replicate pairs, the RPD ranged from 0 to 17 percent, and the RPD for TSS concentrations in environmental/replicate pairs ranged from 2.2 to 80 percent (table 3 ). However, the greatest RPD in a TSS replicate sample coincided with a relatively low concentration in the environmental sample $(8.4 \mathrm{mg} / \mathrm{L})$ and small absolute difference $(4.8 \mathrm{mg} / \mathrm{L})$. For the remaining replicate samples with relatively high RPD (greater than 15 percent), the differences can be attributed mainly to the rapidly changing water-quality conditions that are common with short-term runoff events, because replicate samples were collected in separate bottles immediately after the environmental sample. Data from the WTP-USS site on August 2, 2017, are as an example of how quickly E. coli concentrations can change in stormwater samples collected from the same site. In four samples collected at times separated by an interval of 4 to 14 minutes within a 30-minute period, E. coli concentrations were $4,100 \mathrm{mpn} / 100 \mathrm{~mL}, 120,000 \mathrm{mpn} / 100 \mathrm{~mL}$, $20,000 \mathrm{mpn} / 100 \mathrm{~mL}$, and $11,000 \mathrm{mpn} / 100 \mathrm{~mL}$. Replicate samples of E. coli and fecal coliform bacteria from previous stormwater sampling in Rapid City had a median RPD of about 30 percent (Hoogestraat, 2015). All blank samples for E. coli and TSS were below laboratory reporting levels, indicating satisfactory cleaning procedures and equipment. 
Table 3. Blank and replicate water-quality sample results for samples collected at various stormwater flowpath sites in Rapid City, South Dakota.

[Shading represents the environmental sample. mm/dd/yyyy, month/day/year; hh:mm, hour:minute (military time); mpn/100 mL, most probable number per 100 milliliters; mg/L, milligram per liter; <, less than; --, not available]

\begin{tabular}{|c|c|c|c|c|}
\hline Short identifier (table 1) & Date (mm/dd/yyy) & Time (hh:mm) & $\begin{array}{l}\text { Escherichia coli } \\
(\mathrm{mpn} / 100 \mathrm{~mL})\end{array}$ & Total suspended solids (mg/L) \\
\hline \multicolumn{5}{|c|}{ Equipment blank samples } \\
\hline \multirow{5}{*}{$\begin{array}{l}\text { (Not applicable-Filled at } \\
\text { laboratory) }\end{array}$} & $06 / 13 / 2016$ & $17: 14$ & $<1$ & $<4$ \\
\hline & $06 / 13 / 2016$ & $17: 15$ & $<1$ & $<4$ \\
\hline & $08 / 09 / 2016$ & 08:00 & $<1$ & $<4$ \\
\hline & $05 / 17 / 2017$ & $10: 20$ & $<1$ & $<4$ \\
\hline & $07 / 12 / 2017$ & $14: 50$ & $<1$ & $<4$ \\
\hline \multicolumn{5}{|c|}{ Environmental/replicate sample pairs } \\
\hline EPP-DSP & $07 / 01 / 2016$ & 09:00 & $<10$ & -- \\
\hline EPP-DSP & $07 / 01 / 2016$ & 09:01 & $<10$ & -- \\
\hline Relative percent difference & & & 0 & -- \\
\hline Absolute difference & & & 0 & -- \\
\hline $\mathrm{SDC}-\mathrm{CHN}$ & $05 / 17 / 2017$ & 09:20 & 488 & 8.4 \\
\hline $\mathrm{SDC}-\mathrm{CHN}$ & $05 / 17 / 2017$ & 09:21 & 517 & 3.6 \\
\hline Relative percent difference & & & 5.8 & 80 \\
\hline Absolute difference & & & 29 & 4.8 \\
\hline EPP-PKL & $07 / 12 / 2017$ & $14: 20$ & 727 & 159 \\
\hline EPP-PKL & $07 / 12 / 2017$ & $14: 21$ & 866 & 128 \\
\hline Relative percent difference & & & 17 & 22 \\
\hline Absolute difference & & & 139 & 31 \\
\hline WTP-USS & $08 / 06 / 2018$ & $16: 15$ & 14,200 & 141 \\
\hline WTP-USS & $08 / 06 / 2018$ & $16: 16$ & 16,700 & 138 \\
\hline Relative percent difference & & & 16 & 2.2 \\
\hline Absolute difference & & & 2,500 & 3 \\
\hline
\end{tabular}

\section{Stormwater Quality of Infrastructure Elements}

A complete listing of water-quality sample results from this study are presented in appendix 1, and all data are available from the USGS National Water Information System database (U.S. Geological Survey, 2019). The following sections describe the statistical summaries of water-quality data collected from the Jackson, Wildwood, and Eco Prayer Park flowpaths, as well as a listing of statistics categorized by infrastructure site type. The minimum, median, and maximum concentrations of $E$. coli, TSS, and specific conductance for each sampling site are listed in table 4.

\section{Jackson Flowpath}

In general, the concentrations of E. coli and TSS increased in the downstream direction among the Jackson flowpath sites (table 4). Figure 8 shows an example stormwater-quality data plot for a runoff event on May 24, 2016. The wash-off process after the first flush is evident in the plots for TSS and specific conductance, as noted by the decreasing concentrations with sample time in figures $8 B$ and $8 C$. However, E. coli concentrations do not necessarily follow the same pattern: concentrations in the latter part of the runoff period sampled were similar to or greater than the initial concentrations of the first set of samples (fig. 8A).

Samples collected from the roof downspout site (USGDSP) during the beginning of storm events had relatively low, but quantifiable, amounts of $E$. coli for 50 percent of the storms; final samples collected during the same storm events usually had $E$. coli concentrations below detection levels (appendix 1). TSS concentrations from the roof downspout 


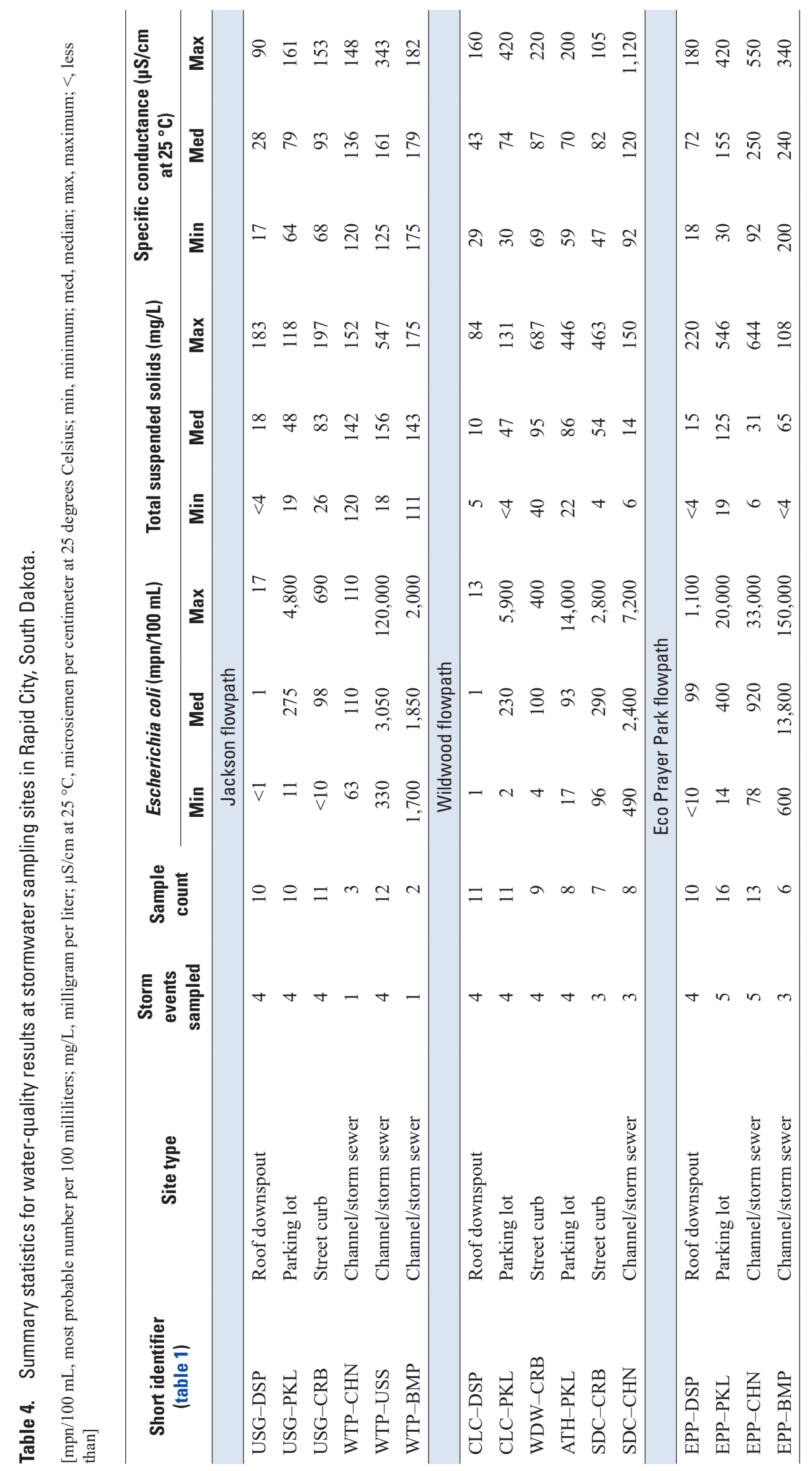



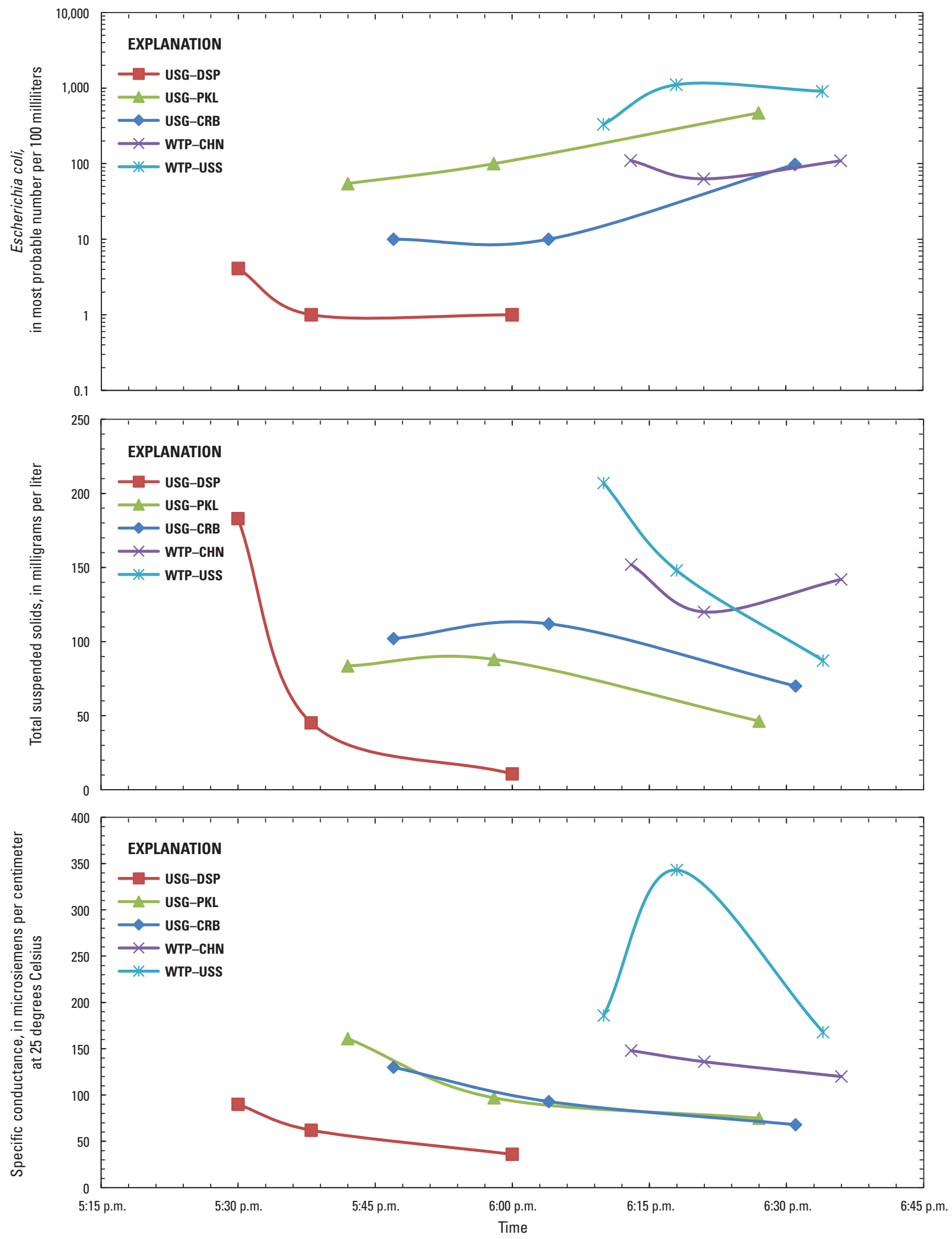

Figure 8. Example stormwater-quality data plot for Jackson flowpath on May 24, 2016. 
site (USGS-DSP) ranged from $183 \mathrm{mg} / \mathrm{L}$ in samples collected during the first flush to less than $(<) 4 \mathrm{mg} / \mathrm{L}$ in samples collected during the later wash-off period of a storm event (table 4). E. coli concentrations from the parking lot (USG$\mathrm{PKL}$ ) and street curb (USG-CRB) sites ranged from $<10$ to $4,800 \mathrm{mpn} / 100 \mathrm{~mL}$ but did not typically show an apparent decreasing (or increasing) pattern during individual storm events, as would be expected with sediment wash-off processes. TSS concentrations from these two sites ranged from about $200 \mathrm{mg} / \mathrm{L}$ in samples collected during the initial flush to about $20 \mathrm{mg} / \mathrm{L}$ in samples collected later during the same storm event. The underground storm sewer site (WTP-USS) farther downstream (where stormwater also collects from the larger drainage network) had the highest $E$. coli concentrations, ranging from 330 to $120,000 \mathrm{mpn} / 100 \mathrm{~mL}$ (median was $3,050 \mathrm{mpn} / 100 \mathrm{~mL}$ ), and had the greatest TSS concentrations, ranging from about $550 \mathrm{mg} / \mathrm{L}$ during the first flush down to about $20 \mathrm{mg} / \mathrm{L}$ after the wash off (median was $156 \mathrm{mg} / \mathrm{L}$ ). Another storm drainage channel (WTP-CHN) joins the flow from WTP-USS, and then flows downstream through a grassed swale BMP (WTP-BMP) before entering Rapid Creek. The flow from the WTP-CHN site was much smaller than the WTP-USS site during all site visits; thus, the WTPBMP location represented mostly (greater than 90 percent) stormwater from the WTP-USS site. Only two samples were collected from the WTP-BMP site during one relatively large storm event compared to other storms in this study. During this large storm on June 27, 2017, the E. coli concentrations ranged from 1,500 to $2,000 \mathrm{mpn} / 100 \mathrm{~mL}$ at the upstream WTP-USS site and were at similar concentrations after flowing through the grassed BMP area (E. coli concentrations ranged from 1,700 to $2,000 \mathrm{mpn} / 100 \mathrm{~mL}$ at the WTP-BMP site). However, TSS concentrations were reduced from a range of 211 to $547 \mathrm{mg} / \mathrm{L}$ at the WTP-USS site to a range of 111 to $175 \mathrm{mg} / \mathrm{L}$ at the WTP-BMP site during this same storm. For the remaining (smaller precipitation) storms when the Jackson flowpath sites were sampled, the flow infiltrated into the grassed areas of the BMP and did not reach the outlet of the flowpath.

\section{Wildwood Flowpath}

In the Wildwood flowpath, E. coli concentrations were lowest in samples collected at the roof downspout site (CLC-DSP) and greatest in samples collected at the main drainage channel (SDC-CHN) farther down the flowpath (table 4). E. coli concentrations at the CLC-DSP site were all $13 \mathrm{mpn} / 100 \mathrm{~mL}$ or less, and the $E$. coli concentration at the SDC-CHN site ranged from 490 to $7,200 \mathrm{mpn} / 100 \mathrm{~mL}$. The parking lot (CLC-PKL and ATH-PKL) and street curb (WDW-CRB and SDC-CRB) sites in the Wildwood flowpath had variable $E$. coli concentrations, ranging from 2 to $14,000 \mathrm{mpn} / 100 \mathrm{~mL}$ with site median values between 93 and $290 \mathrm{mpn} / 100 \mathrm{~mL}$. Contrary to E. coli results, TSS concentrations at the farthest downstream site (SDC-CHN) were lower (median was $14 \mathrm{mg} / \mathrm{L}$ ) than the parking lot and street curb sites (site medians ranged from 47 to $95 \mathrm{mg} / \mathrm{L}$ ). Example stormwater-quality data plots for the Wildwood flowpath are shown in figure 9, demonstrating the first flush and wash-off processes where the TSS concentrations decrease as the runoff hydrograph progresses, whereas the $E$. coli concentrations remain fairly stable or increase.

\section{Eco Prayer Park Flowpath}

Samples collected from the Eco Prayer Park flowpath had higher E. coli concentrations than samples collected from the Jackson and Wildwood flowpath sites. The roof downspout site (EPP-DSP) had a median E. coli concentration of $99 \mathrm{mpn} / 100 \mathrm{~mL}$ for 10 samples, ranging from $<10$ to $1,100 \mathrm{mpn} / 100 \mathrm{~mL}$. The parking lot site (EPP-PKL) and next downstream rock channel site (EPP-CHN) had median concentrations of 400 and $920 \mathrm{mpn} / 100 \mathrm{~mL}$, respectively, with a maximum concentration of $33,000 \mathrm{mpn} / 100 \mathrm{~mL}$ at the EPP-CHN site. The E. coli concentrations from the outlet of the retention pond (EPP-BMP) were greater than the inlet site (EPP-CHN), with a median concentration of $13,800 \mathrm{mpn} / 100 \mathrm{~mL}$ and a maximum $E$. coli concentration of $150,000 \mathrm{mpn} / 100 \mathrm{~mL}$. However, TSS concentrations were reduced by the retention pond and infiltration by the rock channel because the median concentration at the outlet site (EPP-BMP) was $65 \mathrm{mg} / \mathrm{L}$ compared to the parking lot inflow (EPP-PKL) median concentration of $125 \mathrm{mg} / \mathrm{L}$.

Typical water-quality behavior during a runoff event at the Eco Prayer Park sites is demonstrated in figure 10. The dashed line in figure 10 is the retention pond depth, as measured by readings from the stage plate during sampling, and is an estimate of the runoff hydrograph. Water from the retention pond flows into the overflow pipe and connects to the underground storm sewer system when the depth is above 1.3 feet. The sediment washoff process is evident because TSS concentrations decreased during the storm event; however, E. coli concentrations remained fairly constant during the complete runoff period.

\section{Infrastructure Site Type Summary}

A primary objective of this study was to improve on the method by which FIB (for example, E. coli) and TSS are evaluated in the urban drainages within Rapid City, S. Dak. and to provide information that helps identify origins of FIB and TSS. Stormwater quality has been characterized as it enters Rapid Creek during runoff events (Hoogestraat, 2015) and within Rapid Creek itself (Pirner and Harms, 1978; Krantz, 2002), but the data collected in this study help describe the stormwater quality farther upstream in the urban basins. Data collected during this study was summarized by infrastructure site type to provide information about approximate waterquality concentrations at various points along the upper end of urban flowpaths. Median concentrations of E. coli, TSS, 
Stormwater Quality of Infrastructure Elements in Rapid City, South Dakota, 2016-18
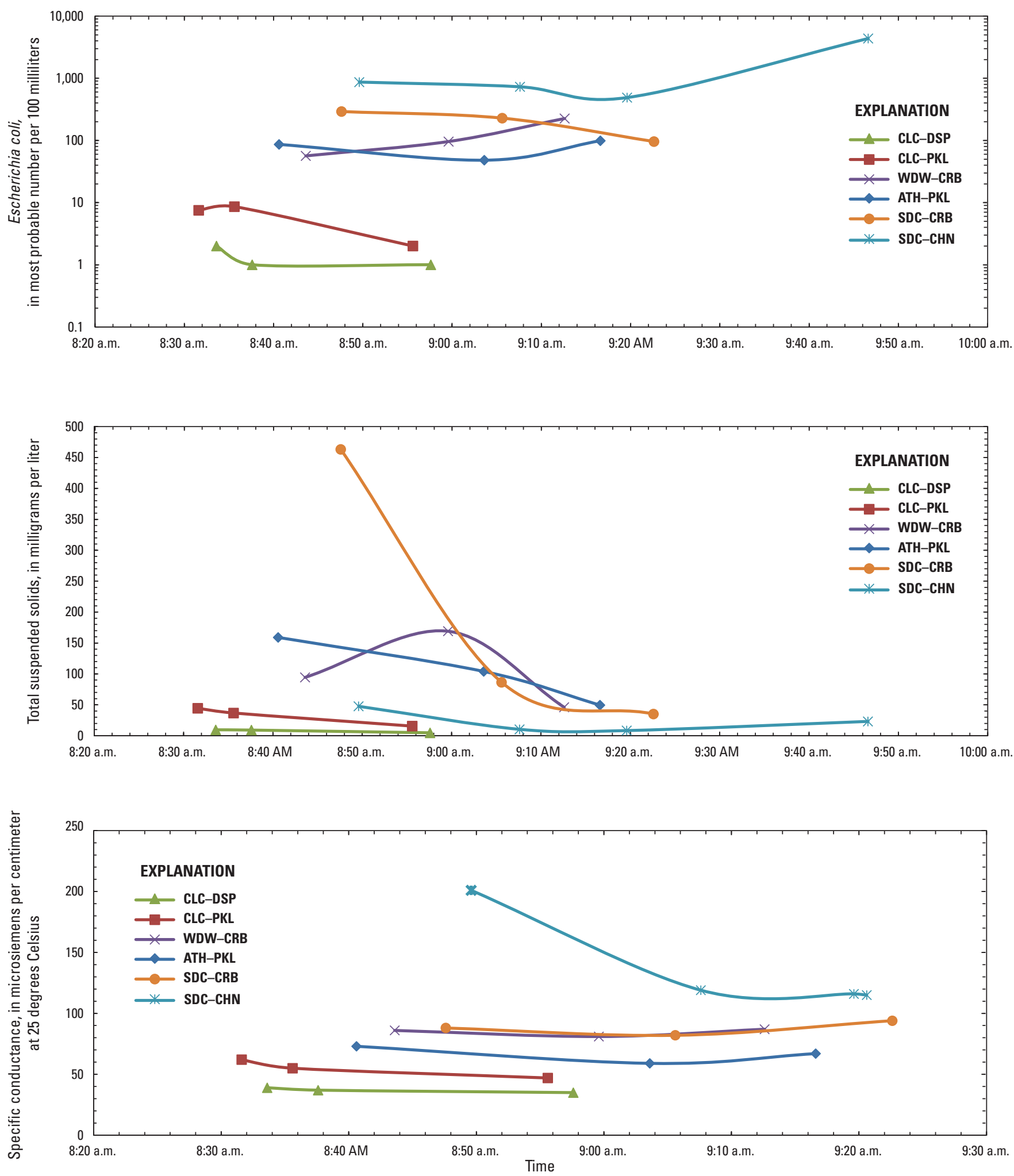

Figure 9. Example stormwater-quality data plot for Wildwood flowpath on May 17, 2017. 

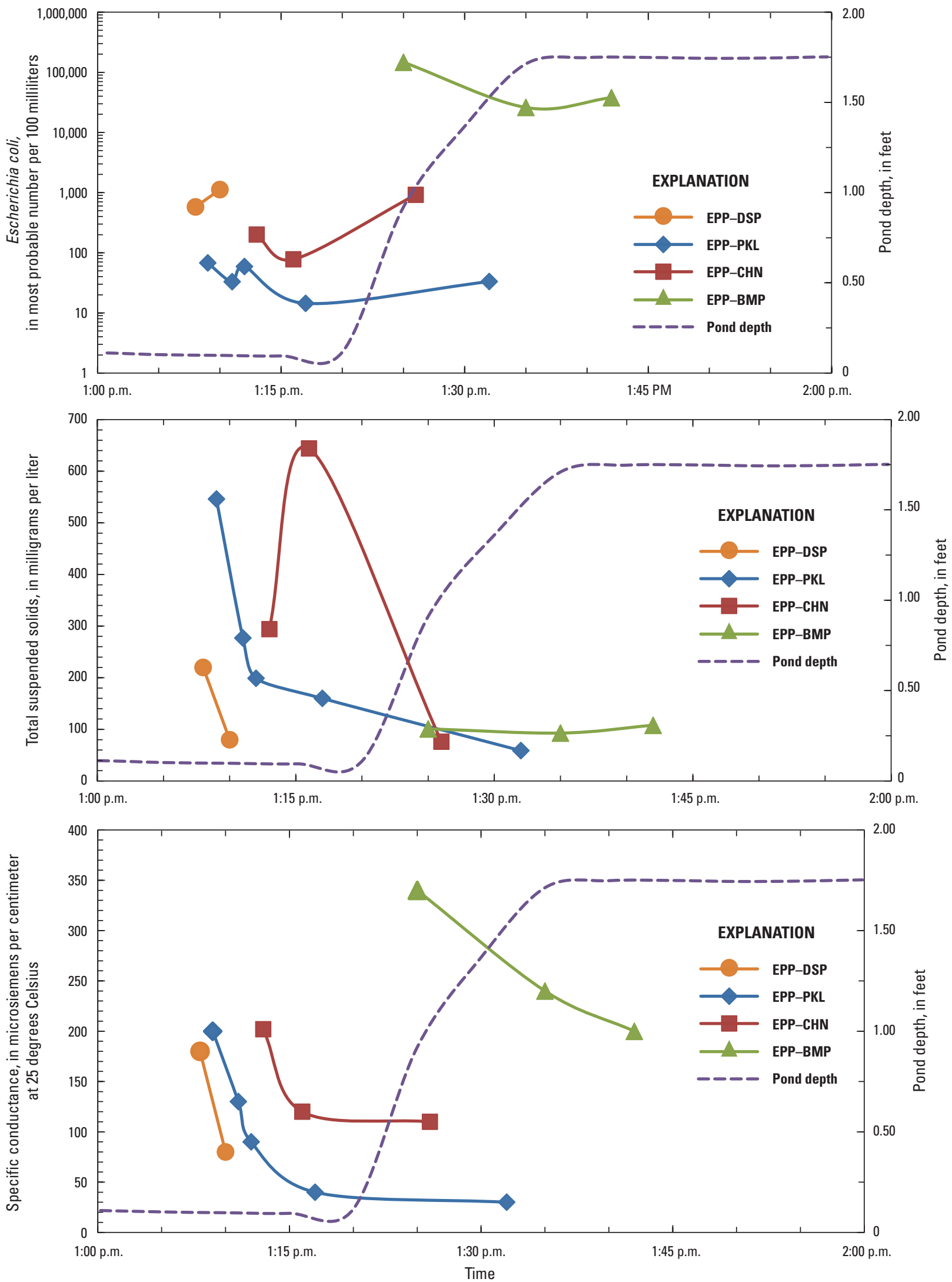

Figure 10. Example stormwater-quality data plot for Eco Prayer Park flowpath on September 12, 2017. 
and specific conductance for the four infrastructure site types that were evaluated for this study (roof downspout, parking lot, street curb, and channel/storm sewer) are listed in table 5. This information can be used in hydrologic models to better estimate FIB and TSS loading from urban environments.

E. coli and TSS concentrations were lowest in samples collected from locations most isolated from human influence (roof downspouts). The median concentrations at these sites were $4 \mathrm{mpn} / 100 \mathrm{~mL}$ and $15 \mathrm{mg} / \mathrm{L}$, respectively. The delivery potential of FIB and sediment from parking lots and street curbs was similar; median concentrations of $E$. coli were around 150 to $220 \mathrm{mpn} / 100 \mathrm{~mL}$ and 56 to $86 \mathrm{mg} / \mathrm{L}$ for TSS. The receiving channels and storm sewers where stormwater was aggregated typically contained the highest $E$. coli concentrations (median of $1,800 \mathrm{mpn} / 100 \mathrm{~mL}$ ), but TSS concentrations were similar to upstream elements (parking lots and street curbs) in the flowpath (median was $69 \mathrm{mg} / \mathrm{L}$ ). For the Wildwood and Eco Prayer Park flowpaths, the median TSS for the channel and storm sewer site types was lower than the upstream elements but not for the Jackson flowpath sites.

Previous research (Schueler, 2000) has suggested that current stormwater, buffer, and source-control practices are incapable of removing enough bacteria to meet current water contact recreation standards in stormwater discharges, unless the discharging water is well mixed and diluted with cleaner water. E. coli concentrations at the outflow sites of most stormwater drainages in Rapid City are about 7,200 to 21,000 mpn/100 mL (Hoogestraat, 2015), and urban drainages account for about 37 percent of the Rapid Creek streamflow at the downstream boundary of Rapid City. It is probable that bacterial concentrations in streams that receive stormwater runoff will always exceed predevelopment conditions, even if stormwater treatment and buffer practices are fully implemented and all wastewater discharges are eliminated (Schueler, 2000). The current beneficial-use criterion for E. coli in Rapid Creek is $235 \mathrm{mpn} / 100 \mathrm{~mL}$, which is only slightly greater than the median concentration that washes off parking lots and street curbs in the upstream end of the urban flowpath (median of 150 to $220 \mathrm{mpn} / 100 \mathrm{~mL}$ ). The data collected from this study demonstrate that stormwater is almost immediately contaminated with FIB upon touching impervious surfaces, which highlights the importance of controlling the volume of stormwater discharges into receiving waterbodies via storage structures and pervious elements. An example of this reduction in volume is the observations from the BMP area sampled in the Jackson flowpath during this study, where flow during smaller storms were completely infiltrated into the grassed channels before reaching the outlet into Rapid Creek. Diluting stormwater containing high concentrations of $E$. coli with the receiving water's (Rapid Creek) lower concentration of $E$. coli is likely the primary mechanism for meeting the $235 \mathrm{mpn} / 100 \mathrm{~mL}$ beneficial-use criterion threshold.

TSS concentrations in the upstream end of the urban flowpath (parking lots and street curbs) also begin at concentrations ( 56 to $86 \mathrm{mg} / \mathrm{L}$ ) above the beneficial-use criterion for Rapid Creek (53 mg/L); however, previous research has indicated that current stormwater-control practices (storage ponds, swales, wetlands) were able to reduce suspended-sediment concentrations by 40 to 60 percent (Hoogestraat, 2015). The BMP area in the lower end of the Jackson flowpath is another example of how a stormwater-control practice can reduce TSS concentrations. TSS concentrations were reduced from a peak of $547 \mathrm{mg} / \mathrm{L}$ at the inflow to the BMP area (WTP-USS site) to concentrations less than $200 \mathrm{mg} / \mathrm{L}$ at the outlet site (WTPBMP) during this same event. Dilution with receiving waters is not the only mechanism for meeting beneficial-use criteria for TSS because concentrations of TSS in the upstream end of Rapid City stormwater flowpaths were generally closer to the criterion when compared to the difference between $E$. coli concentrations and the corresponding criterion. For example, in order for stormwater to meet the TSS beneficial-use criterion of Rapid Creek ( $53 \mathrm{mg} / \mathrm{L}$ ), the median concentration of TSS from street curbs during this study $(86 \mathrm{mg} / \mathrm{L})$ would need to be reduced by 39 percent, which is within the expected range of most current stormwater-control practices.

Table 5. Median Escherichia coli concentration, total suspended solids concentration, and specific conductance of site types sampled in 2016-18, Rapid City, South Dakota.

[mpn/100 mL, most probable number per 100 milliliters; $\mathrm{mg} / \mathrm{L}$, milligram per liter; $\mu \mathrm{S} / \mathrm{cm}$ at $25{ }^{\circ} \mathrm{C}$, microsiemen per centimeter at 25 degrees Celsius ]

\begin{tabular}{lccc}
\hline & & \multicolumn{2}{c}{ Median concentration } \\
\cline { 2 - 4 } & \begin{tabular}{c} 
Site type \\
\cline { 2 - 4 }
\end{tabular} & $\begin{array}{c}\text { Total suspended solids }(\mathbf{m g} / \mathbf{L}) \\
\mathbf{1 0 0} \mathbf{~ m L )}\end{array}$ & $\begin{array}{c}\text { Specific conductance }(\boldsymbol{\mu S} / \mathbf{c m} \text { at } \\
\left.\mathbf{2 5}{ }^{\circ} \mathbf{C}\right)\end{array}$ \\
\hline Roof downspout & 4 & 15 & 43 \\
Parking lot & 220 & 56 & 93 \\
Street curb & 150 & 86 & 87 \\
Channel/ & 1,800 & 69 & 176 \\
\hline storm sewer & & & 87 \\
\hline
\end{tabular}




\section{Summary}

As runoff flows over the land or impervious surfaces (paved streets, parking lots, and building roofs), it accumulates debris, chemicals, sediment, and other contaminants that can adversely affect water quality if the runoff discharge remains untreated. Fecal indicator bacteria (FIB), such as Escherichia coli (E. coli), enterococci, or fecal coliform, are the most-frequent cause of water-quality impairment in rivers and streams in the United States. Rapid Creek originates in the western Black Hills area and flows east through Rapid City to its mouth at the Cheyenne River. The water quality of Rapid Creek is important because the reach that flows through Rapid City, South Dakota, is a valuable spawning area for a selfsustaining trout fishery, is actively used for recreation, and is a seasonal municipal water supply for the City of Rapid City. The fishery and recreational uses are considered "beneficial uses" by the South Dakota Department of Environment and Natural Resources, which carry numerical criteria for total suspended solids (TSS) and E. coli concentrations, among other water-quality constituents for additional beneficial uses. Current methods of identifying FIB impairments in surface water are usually limited to a general assessment of sources (typically grouped as livestock, wildlife, or human), and FIB sample data relative to specific sources typically are not available. The objectives of this study were to improve on the method by which FIB and TSS are quantified in the urban drainages within Rapid City and to provide information that helps identify origins of FIB and TSS. This information can be used in hydrologic models to estimate FIB and TSS loading from certain infrastructure elements in urban environments.

Stormwater-quality data were collected in three drainage basin flowpaths within Rapid City: Jackson, Wildwood, and Eco Prayer Park. Data-collection activities for this study focused on the beginning urban flowpath elements during rainfall events, including building roofs, parking lots, street curbs, and drainage channels. This approach builds upon previous stormwater assessments that characterized the water quality in urban basin outlets near the downstream end of the stormwater flowpaths. Within each flowpath group, 4-6 sites were selected to represent the various infrastructure elements of the runoff process. These elements included roof downspouts, parking lots, street curbs and gutters, open channels, underground storm sewers, and stormwater ponds or best-management practice facilities. Water-quality samples were collected at each flowpath site during storm events during May-September in 2016-18. Multiple samples were collected at each flowpath site during runoff events to capture the variability in waterquality concentrations as the runoff hydrograph rises ("first flush" process) and falls after the peak runoff flow (when material from impervious surfaces have "washed off"). A total of 147 water-quality samples were analyzed for E. coli, TSS, specific conductance, and $\mathrm{pH}$.

In general, the concentrations of E. coli and TSS increased in the downstream direction among the Jackson flowpath sites. The wash-off process after the first flush was evident in the plots for TSS and specific conductance; however, E. coli concentrations did not necessarily follow the same pattern. E. coli concentrations in the latter part of the runoff period were similar to or greater than the initial concentrations of the first set of samples. In the Wildwood flowpath, E. coli concentrations were lowest at the roof downspout site (less than or equal to 13 most probable number per 100 milliliters $[\mathrm{mpn} / 100 \mathrm{~mL}]$ ) and greatest at the main drainage channel farther down the flowpath (ranged from 490 to $7,200 \mathrm{mpn} / 100 \mathrm{~mL}$ ). The parking lot and street curb sites' $E$. coli concentrations in the Wildwood flowpath ranged from 2 to $14,000 \mathrm{mpn} / 100 \mathrm{~mL}$; site median values were between 93 and $290 \mathrm{mpn} / 100 \mathrm{~mL}$. Contrary to E. coli results, TSS concentrations at the lowest stormwater channel site were lower (median was 14 milligrams per liter $[\mathrm{mg} / \mathrm{L}]$ ) than the parking lot and street curb sites (site medians ranged from 47 to $95 \mathrm{mg} / \mathrm{L}$ ). In the Eco Prayer Park flowpath, E. coli concentrations were greater than the other two flowpath groups. The Eco Prayer Park parking lot site and next downstream rock channel site had median E. coli concentrations of 400 and $920 \mathrm{mpn} / 100 \mathrm{~mL}$, respectively, with a maximum concentration of 33,000 mpn/100 mL. TSS concentrations were reduced by the retention pond within the Eco Prayer Park because the median concentration at the outlet site was $65 \mathrm{mg} / \mathrm{L}$ compared to a parking lot median concentration of $125 \mathrm{mg} / \mathrm{L}$.

Data collected during this study were summarized by infrastructure type (roof downspout, parking lot, street curb, and channel/storm sewer) to provide information about approximate water-quality concentrations at various points along the upper end of urban flowpaths. E. coli and TSS concentrations were lowest in samples collected from locations most isolated from human, animal, or both influences (roof downspouts). The median concentrations at these roof downspout sites were $4 \mathrm{mpn} / 100 \mathrm{~mL}$ and $15 \mathrm{mg} / \mathrm{L}$, respectively. The delivery potential of FIB and sediment from parking lots and street curbs was similar, with median concentrations of E. coli and TSS around 150 to $220 \mathrm{mpn} / 100 \mathrm{~mL}$ and 56 to $86 \mathrm{mg} / \mathrm{L}$, respectively. The downstream receiving channels and storm sewers where stormwater was aggregated typically contained the highest $E$. coli concentrations (median of $1,800 \mathrm{mpn} / 100 \mathrm{~mL}$ ), but the TSS concentrations were similar to upstream elements (parking lots and street curbs) in the flowpath (median was $69 \mathrm{mg} / \mathrm{L}$ ). The data collected from this study demonstrate that stormwater is almost immediately contaminated with FIB upon contacting impervious surfaces. This highlights the importance of controlling the volume of stormwater discharges into receiving waterbodies via storage structures and pervious elements. Diluting stormwater with high concentrations of E. coli with the receiving water's (Rapid Creek) lower concentration of $E$. coli is likely the primary mechanism for meeting the $235 \mathrm{mpn} / 100 \mathrm{~mL}$ beneficial-use criterion threshold. Although TSS concentrations in the upper ends of the basin (parking lots and street curbs) also begin at concentrations (56 to $86 \mathrm{mg} / \mathrm{L}$ ) above the beneficial-use criterion for Rapid Creek (53 mg/L), current stormwater-control 
practices (storage ponds, swales, and wetlands) may be able to reduce suspended-sediment concentrations to meet this threshold.

\section{References Cited}

American Public Health Association, 2015, Standard methods for the examination of water and wastewater: Washington, D.C., American Public Health Association, American Water Works Association, and Water Environment Federation, accessed March 18, 2015, at https://www.standardmethods.org/.

American Society of Civil Engineers, 2014, Pathogens in urban stormwater systems: Urban Water Resources Research Council, accessed March 18, 2016, at https://stormwater.wef.org/2014/10/ewri-releases-reportpathogens-urban-stormwater-systems.

Driscoll, D.G., Bunkers, M.J., Carter, J.M., Stamm, J.F., and Williamson, J.E., 2010, Thunderstorms and flooding of August 17, 2007, with a context provided by a history of other large storm and flood events in the Black Hills area of South Dakota: U.S. Geological Survey Scientific Investigations Report 2010-5187, 139 p. [Also available at https://doi.org/10.3133/sir20105187.]

Granato, G.E., and Smith, K.P., 1999, Estimating Concentrations of Road-Salt Constituents in HighwayRunoff from Measurements of Specific Conductance: U.S. Geological Survey Water-Resources Investigations Report 99-4077. [Also available at https://pubs.usgs.gov/ wri/wri99-4077/.]

Granato, G.E., 2013, Stochastic empirical loading and dilution model (SELDM) version 1.0.0: U.S. Geological Survey Techniques and Methods, book 4, chap. C3, 112 p. [Also available at https://pubs.usgs.gov/tm/04/c03.]

Hem, J.D., 1985, Study and interpretation of chemical characteristics of natural water ( $3 \mathrm{~d}$ ed.): U.S. Geological Survey Water-Supply Paper 2254, 263 p. [Also available at https://pubs.usgs.gov/wsp/wsp2254/.]

Hoogestraat, G.K., 2015, Water-Quality Characteristics of Stormwater Runoff in Rapid City, South Dakota, 2008-14: U.S. Geological Survey Scientific Investigations Report 2015-5069, 27 p. [Also available at https://doi.org/10.3133/ sir20155069.]

Krantz, E.L., 2002, Urban runoff water-quality impacts to brown trout (Salmo trutta) in Rapid Creek, Rapid City, South Dakota: Rapid City, South Dakota School of Mines and Technology, M.S. Thesis, 115 p.
National Oceanic and Atmospheric Administration, 2014, Data tools-1981-2010 normals: National Climatic Data Center, accessed October 28, 2014, at https://www.ncdc.noaa.gov/ cdo-web/datatools/normals.

Pirner, S., and Harms, L.L., 1978, Rapid City combats the effects of urban runoff on surface water: Water \& Sewage Works, v. 125 , no. 2, p. 48-53.

Prann, R.A., 2013, Modeling the effect of urbanization on two watersheds in Rapid City, SD using SWMM: Rapid City, South Dakota School of Mines and Technology, M.S. Thesis, $121 \mathrm{p}$.

Riebschleager, K.J., Karthikeyan, R., Srinivasan, R., and McKee, K., 2012, Estimating potential E. coli sources in a watershed using spatially explicit modeling techniques: Journal of the American Water Resources Association, v. 48, no. 4, p. 745-761. [Also available at https://doi.org/10.1111/ j.1752-1688.2012.00649.x.]

Schueler, T., 2000, Microbes and urban watersheds-Ways to kill 'em-The practice of watershed protection: Ellicott City, Md., Center for Watershed Protection, p. 392-400, accessed October 29, 2019, at https://owl.cwp.org/mdocsposts/elc_pwp67/.

South Dakota Department of Environment and Natural Resources, 2010, Surface water quality standards: South Dakota Department of Environment and Natural Resources web page, accessed June 22, 2010, at http://denr.sd.gov/des/ sw/swqstandards.aspx.

South Dakota Department of Environment and Natural Resources, 2014, The 2014 South Dakota integrated report for surface water quality assessment: South Dakota Department of Environment and Natural Resources report, 248 p., accessed October 15, 2014, at http://denr.sd.gov/des/ sw/IntegratedReports.aspx.

South Dakota Department of Environment and Natural Resources, 2019, Nonpoint source pollution total maximum daily loads (TMDLs): South Dakota Department of Environment and Natural Resources web page, accessed July 24, 2019, at http://denr.sd.gov/dfta/wp/tmdl.aspx.

Tiefenthaler, L., Stein, E., and Schiff, K.C., 2011, Levels and patterns of fecal indicator bacteria in stormwater runoff from homogenous land use sites and urban watersheds: Journal of Water and Health, v. 9, no. 2, p. 279-290. [Also available at https://doi.org/10.2166/wh.2010.056.]

U.S. Census Bureau, 2019, QuickFacts-Rapid City city, South Dakota: U.S. Census Bureau, digital data, accessed September 23, 2019, at https://www.census.gov/quickfacts/ rapidcitycitysouthdakota. 
U.S. Environmental Protection Agency, 1983, Results of the nationwide urban runoff program-Executive summary: U.S. Environmental Protection Agency, Water Planning Division, WH-554, 24 p., accessed October 29, 2019, at https://www3.epa.gov/npdes/pubs/sw_nurp_exec_ summary.pdf.

U.S. Environmental Protection Agency, 2000, Bacterial indicator too-User's guide. Washington, DC., U.S. Environmental Protection Agency, Office of Water, EPA-823-B-01-003, accessed October 29, 2019, at https://nepis.epa.gov/Exe/ZyPURL.cgi?Dockey= P100O179.TXT.

U.S. Environmental Protection Agency, 2010, Stormwater phase II final rule fact sheet series: U.S. Environmental Protection Agency, National Pollutant Discharge Elimination System web page, accessed October 11, 2019, at https://www.epa.gov/npdes/stormwater-phase-ii-finalrule-fact-sheet-series.
U.S. Environmental Protection Agency, 2019, National summary of State information: U.S. Environmental Protection Agency, accessed October 24, 2019, at https://ofmpub.epa.gov/waters10/attains_nation_cy.control.

U.S. Geological Survey, 2006, Collection of water samples (ver. 2.0): U.S. Geological Survey Techniques of WaterResources Investigations, book 9, chap. A4, accessed July 26, 2019, at https://doi.org/10.3133/twri09A4.

U.S. Geological Survey, 2019, USGS water data for the Nation: U.S. Geological Survey National Water Information System database, accessed September 5, 2019, at https://doi.org/10.5066/F7P55KJN.

Wilde, F.D., ed., 2004, Cleaning of equipment for water sampling (ver. 2.0): U.S. Geological Survey Techniques of Water-Resources Investigations, book 9, chap. A3, accessed July 26, 2019, at https://doi.org/10.3133/twri09A3. 


\section{Appendix 1 Stormwater-Quality Data}

Appendix 1 is a comma-separated values (.csv) file that contains the water-quality sample results for data used in this report and is available for download at https://doi.org/10.3133/ sir20205004. These data are also stored in the USGS National Water Information System database (U.S. Geological Survey, 2019) and are packaged herein for convenience.

\section{Reference Cited}

U.S. Geological Survey, 2019, USGS water data for the Nation: U.S. Geological Survey National Water Information System database, accessed September 5, 2019, at https://doi.org/10.5066/F7P55KJN. 



\section{$\frac{\mathbb{2}}{\mathrm{C}}$}

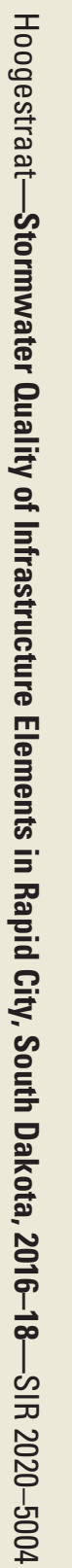

